CENTRE for ECONOMIC

$P$ E R F O R M A N C E

CEP Discussion Paper No 1578

October 2018

\title{
The Not-So-Generalized Effects of the Generalized System of Preferences
}

\author{
Emanuel Ornelas \\ Marcos Ritel
}




\begin{abstract}
We use an empirical gravity equation approach to study how nonreciprocal trade preferences (NRTPs), enacted mainly through the Generalized System of Preferences, affect the exports of the beneficiary nations. In line with existing studies, the average trade effect stemming from nonreciprocal preferences is highly unstable across specifications. However, once we allow for heterogeneous effects, results become robust and economically important. Specifically, NRTPs have a strong effect on the exports of beneficiaries when they are members of the World Trade Organization and are very poor. Not-so-poor beneficiaries also expand foreign sales, but only if they are not WTO members. For all others, the average export effects of NRTPs are mute.
\end{abstract}

Key words:trade preferences, gravity equation, trade policy, nonreciprocity, GSP JEL Codes: F13; F14; F15; F55; F63; O19; O24

This paper was produced as part of the Centre's Trade Programme. The Centre for Economic Performance is financed by the Economic and Social Research Council.

We thank Salvador Gil-Pareja, Rafael Llorca-Vivero, Xuepeng Liu, Jose Martinez-Serrano, Joao Paulo Pessoa, Christian Henn and seminar participants at the 20th European Trade Study Group annual conference, at the 21th LACEA Annual Meeting, at the 2nd International REAP \& SBE Meetings and at the Sao Paulo School of Economics for very helpful comments. Special thanks go to Arevik Gnutzmann-Mkrtchyan and Ben Zissimos for particularly detailed and useful comments and suggestions. Ornelas acknowledges financial support from the Brazilian Council of Science and Technology (CNPq). Ritel acknowledges financial support from the Coordenacao de Aperfeicoamento de Pessoal de Nivel Superior (CAPES).

Emanuel Ornelas, Sao Paulo School of Economics-FGV, CEPR, CESifo and Centre for Economic Performance, London School of Economics. Marcos Ritel, Sao Paulo School of Economics-FGV.

Published by

Centre for Economic Performance

London School of Economics and Political Science

Houghton Street

London WC2A 2AE

All rights reserved. No part of this publication may be reproduced, stored in a retrieval system or transmitted in any form or by any means without the prior permission in writing of the publisher nor be issued to the public or circulated in any form other than that in which it is published.

Requests for permission to reproduce any article or part of the Working Paper should be sent to the editor at the above address.

C E. Ornelas and M. Ritel, submitted 2018. 


\section{Introduction}

A cornerstone of the world trading system is the idea, represented in several articles of the General Agreement on Tariffs and Trade (GATT), that developing countries should receive "special and differential treatment." Such a special treatment comes in many forms, but is most visible in the Generalized System of Preferences (GSP). Those preferences have been firmly in place since the early 1970s, and apply over a sizeable share of the exports from developing economies. Currently, all industrialized nations have a GSP program. It is also common to have more privileged preference programs, sometimes restricted to Least Developed Countries (LDCs), sometimes limited to developing nations from a specific region. More recently, even some emerging economies have put in place their own GSPs. For brevity, we call the programs of nonreciprocal trade preferences collectively by nonreciprocal trade preferences, or NRTPs; currently, there are 27 of them in force. ${ }^{1}$

The formal goal of NRTPs is to foster economic growth in developing economies. Yet, despite the longevity of the system and its potential importance for developing countries and for the multilateral trading system more generally, the empirical evidence on the effectiveness of nonreciprocal preferences is lacking in many ways. In fact, we do not have even a clear picture of their effects on aggregate exports. Some authors argue that NRTPs have a large and positive effect on the exports of beneficiaries. Others indicate that they have a large but negative effect. Some studies point instead to ambiguous effects. This is troubling, because if we hope to assess the effectiveness of nonreciprocal trade preferences in promoting economic growth, we need to know at least their effects on beneficiaries' exports. Since the United States is currently tightening the enforcement of eligibility criteria for recipients of its NRTPs, such an assessment seems particularly timely. ${ }^{2}$

In this short paper, we aim to fill this gap. Using data between 1950 and 2015, we establish some key facts about the aggregate trade effects of NRTPs employing a standard but theoretically consistent gravity equation framework. At least as importantly, we use a recent, carefully constructed dataset put together by Scott Baier and Jeffrey Bergstrand,

\footnotetext{
${ }^{1}$ See Ornelas (2016) for a detailed discussion of the institutional setting of GSP and of other forms of the special and differential treatment offered to developing countries in the world trading system, and Zissimos (2018) for a collection of articles discussing the various roles of the World Trade Organization in economic development.

${ }^{2}$ As U.S. Trade Representative Robert Lighthizer recently indicated, "President Trump has sent a clear message that the United States will vigorously enforce eligibility criteria for preferential access to the U.S. market. Beneficiary countries choose to either work with USTR to meet trade preference eligibility criteria or face enforcement actions" (https://ustr.gov/about-us/policy-offices/press-office/pressreleases/2017/december/trump-administration-enforces).
} 
which to our knowledge has not been used to scrutinize the effects of NRTPs yet.

In line with the received literature, we find that NRTPs do not have a clear effect on the average exports of beneficiary countries. They do promote exports of LDC beneficiariesbut only if they are members of the World Trade Organization (WTO). In that case, NRTPs increase trade significantly. In contrast, other developing economies that receive nonreciprocal preferences are also able to increase exports, but only if they are not WTO members. For all others, the average export effects of NRTPs are essentially mute. Those findings are robust to different econometric specifications and different trade agreement definitions, and are observed across most of the decades covered in our dataset.

Hence, the upshot of our analysis is that we need to allow for heterogeneity to understand the effects of NRTPs, as they are effective in promoting aggregate exports of beneficiary countries only under some circumstances. In particular, the results point to interesting linkages between the export benefits from participation in the WTO (where tariff concessions are negotiated multilaterally and are nondiscriminatory) and the benefits from nonreciprocal, preferential tariff concessions. For some types of economies, they are complementary to each other; for others, they are substitutes.

It is beyond the scope of this paper to investigate the reasons leading to such a stark heterogeneity, but our findings can be rationalized. For non-LDCs, the results are intuitive. Nonreciprocal preferences help if the country does not have secure access to developed markets through (generally low) MFN tariffs; once they do, the extra market access through (revocable and therefore insecure) NRTPs become less important. ${ }^{3}$ For LDCs, on the other hand, NRTPs complement the market access gains that they accrue from participating in the WTO. That result is less immediate. Yet an important factor behind the ineffectiveness of NRTPs for very poor countries that are not WTO members may be the difficulties those countries face in accessing world markets due to both lacking infrastructure and distorted incentives. Once they become members of the WTO, an event that usually prompts (and is prompted by) other institutional reforms, resources can more easily flow to comparative advantage sectors, allowing them to effectively take advantage of the preferences. We provide suggestive evidence that, indeed, institutions (as proxied, for example, by a democracy index) are central to explain the effectiveness of NRTPs for LDCs.

Now, it is important to stress that, even if we were absolutely sure that NRTPs boosted

\footnotetext{
${ }^{3}$ Carnegie (2013) shows that WTO rules weaken the leverage that larger economies have over smaller ones once they becomes members. As a result, the 'donor' countries tend to make the threat of GSP revocation more salient to achieve international political goals. Such increased insecurity of GSP eligibility could also help to explain this finding.
} 
exports for some groups of countries, this would constitute an important but only the first element in a thorough assessment of the desirability of NRTPs. For starters, the theoretical basis for NRTPs is shaky (see, e.g., Bagwell and Staiger, 2014). In particular, they stand in stark contrast with the principles of reciprocity (the preferences are unilateral) and of nondiscrimination (they discriminate across sources of imports by design), the two main pillars of the world trading system (Bagwell and Staiger, 1999, 2002). Furthermore, because preferences are given and taken at the discretion of the "donor" countries, the continuity of the improved market access is uncertain. But as Limao (2016) makes clear, such trade policy uncertainty can undermine the effectiveness of preferential market access.

\subsection{Related Literature}

We build on a broad literature that estimates ex-post trade effects of trade agreements on aggregate bilateral imports using a gravity equation. ${ }^{4}$ Even though NRTPs have been a staple of the world trading system since the 1970s, there are surprisingly few papers whose primary goal is to study NRTPs. However, the literature concerned with the trade effects of WTO membership has always included in its empirical specifications controls for GSP status. Hence, a large part of research on the trade effects of NRTPs can be viewed as an "incidental literature," whose main concern lies elsewhere. Put together, results are all over, depending on the empirical specification and the dataset used. ${ }^{5}$

Rose (2004), Subramanian and Wei (2007) and Liu (2009) are some of the main studies that estimate the trade effect of GSP as a by-product of their analyses of the WTO trade effect. By itself, this is not a problem. However, the main drawbacks in their analyses are the use of average trade as the dependent variable (Rose)-according to Baldwin and Taglioni (2006), this corresponds to the "silver medal mistake," which is especially problematic in one-way trade arrangements - the lack of proper control for multilateral resistance (both Rose and Liu), as proposed by Anderson and Van Wincoop (2003), and the absence of control for time-invariant country-pair heterogeneity (Subramanian and Wei). As Head and Mayer (2014) make clear, all of that matters. Furthermore, Rose codes GSP as a bilateral variable, but by definition it represents unilateral trade preferences.

\footnotetext{
${ }^{4}$ See Limao (2016) for a recent and insightful review of the branch of that literature dealing with reciprocal preferences in the context of preferential trade agreements.

${ }^{5}$ We direct the reader to Ornelas (2016, section 4.2) for a more detailed discussion of this literature and its controversial and diverse results. Here we only highlight what we believe are the main sources of disagreement about the results. Ornelas (2016) does not, however, discuss the problems arising from the different sources of data on NRTPs used in the literature, one of our emphases here.
} 
In terms of results, Rose (2004) and Subramanian and Wei (2007) find very large positive trade effects for GSP, although Subramanian and Wei obtain contrasting results when disaggregating by main sector of activity. Chang and Lee (2011) reach the same conclusion using non-parametric methods, but recognizing that their framework is not well suited to control for endogenous multilateral resistance terms. On the other hand, Liu (2009) obtains mixed results, which vary with the specification.

Herz and Wagner (2011) and Gil-Pareja et al. (2014) do place NRTPs at the center of their analysis. Eicher and Henn (2011) also discuss the effects of NRTPs, although their main goal is to estimate the trade effect of Preferential Trade Agreements (PTAs), individually and as a whole. Herz and Wagner do not control for multilateral resistance, but Eicher and Henn and Gil-Pareja et al. do. All of them include country-pair fixed effects. ${ }^{6}$

Now, a problem with those papers, as well as with the preceding incidental literature, is the source of data on GSP and other NRTPs. Take for example Eicher and Henn (2011). They use the data for GSP from Subramanian and Wei (2007), who in turn use Rose's (2004) data. But Rose simply uses UNCTAD's reports in 1974, 1979 and 1984, therefore disregarding all subsequent changes in GSP. Furthermore, Eicher and Henn only code GSP from 1979 onwards, although the European GSP program started in 1971 and the American in 1976. In turn, Gil-Pareja et al. (2014) use UNCTAD's reports in 2001, 2005, 2006 and 2008. For previous years, they rely on Herz and Wagner's (2011) data, which Herz and Wagner credit to the UNCTAD but without giving further details. Liu (2009) is particularly careful about his GSP coding, sourcing from all available UNCTAD reports up to 2003, the last year in his dataset. A problem remains, however, for the several years when there is no UNCTAD report, since changes in GSP membership typically happen at a higher frequency. The standard solution in the literature has been to simply interpolate data from the nearest available years, but this is obviously unsatisfactory. Finally, of all the papers mentioned above, only Gil-Pareja et al. (2014) are especially careful with the coding of non-GSP NRTPs, which they obtain from the agreements' websites. Nonetheless, they individually code only five of such arrangements, whereas twenty two of them were in force in the last year of their dataset.

\footnotetext{
${ }^{6}$ Gil-Pareja et al. (2017) use the same dataset as Gil-Pareja et al. (2014) to study instead how NRTPs affect the exports of the countries offering the preferences to those receiving them. They find sizeable and statistically significant positive effects in their OLS specification with country-year and country-pair fixed effects. They rationalize their findings by arguing that nonreciprocal preferences usually have additional requirements, such as enforcement of intellectual property rights and rules of origin, which could have a positive trade effect for the countries offering the preferences.
} 
Those differences about the sources of information on NRTPs would matter little if estimates were very stable across studies. They are not. For example, Eicher and Henn (2011) find that GSP trade effects are large, negative and significant. This is also the main conclusion of Herz and Wagner (2011). In contrast, Gil-Pareja et al. (2014) obtain the opposite result (although not for all NRTPs), more in line with the incidental findings from the WTO-trade-effect literature. Overall, the magnitude and the statistical significance of the results vary tremendously across studies, and sometimes even within studies, making it difficult to establish the main facts about the aggregate effects of NRTPs.

There is also a valuable but still small literature that estimates the trade effects of specific nonreciprocal trade preferences using product-level bilateral trade data. Frazer and Van Biesebroeck (2010) study the African Growth and Opportunity Act (AGOA); Thelle et al. (2015) analyze the effects of all European NRTPs. Both studies find that nonreciprocal preferences promote the exports of recipient countries. In line with our results, Thelle et al. (2015) find effects that are twice as large for LDCs. Hakobyan (2017a, 2017b) uses a similar disaggregated approach to study the American GSP program, exploiting periods in which the program had expired (to be later reinstated) and the suspension of some country-product pairs from the program after exports to the U.S. increased "too much." In both cases, she finds evidence that the program promotes the exports of recipient countries, although the effects using the first approach are rather modest. Gnutzmann and Gnutzmann-Mkrtchyan (2017) study the E.U.'s withdrawal of GSP preferences from Belarus in 2007 and find negative effects for (4-digit) products directly affected, but no aggregate trade effect. In recent work, Garred and Kwon (2017) study the effects of the expansion of unilateral preferences in OECD economies to LDCs since the late 1990s. They find small positive effects at the extensive margin (by country pair and product), which are present only when a beneficiary country already exported the product elsewhere or exported other products to the preference-granting market.

Our analysis differs from those lines of research because here the aim is to investigate NRTPs as a global trade policy alternative. We recognize that disaggregated data can allow for more precise identification. In fact, as Ornelas (2016) points out, determining causality and identifying underlying mechanisms will be possible only once the literature moves to firm-level analysis and exploits reasonably exogenous trade shocks. ${ }^{7}$ Nevertheless,

\footnotetext{
${ }^{7}$ To our knowledge, there are only two ongoing attempts at that. Albornoz et al. (2018) study the American GSP exploiting a partial suspension of Argentina's preferences starting in 1997. They find that the preferences promote exports, although the effect is almost entirely driven by the extensive margin. Teti (2018) also finds positive effects for Peruvian firms due to the Andean Trade Preferences Act, a program
} 
understanding the impact of nonreciprocal preferences on aggregate trade flows is a critical initial step before we can move in that direction and towards quantification of their welfare and efficiency properties. We seek to provide that first step here.

The paper is organized as follows. We discuss the data in the next section and the empirical strategy in section 3 . In section 4 we show our results and conclude in section 5 .

\section{Data}

We have an unbalanced panel with nearly 1.5 million observations, where the main variable is annual bilateral aggregate imports obtained from the 3.0 version of the Correlates of War database, which covers trade from 1950 to $2009 .^{8}$ We complete the dataset with import data from the IMF's Direction of Trade Statistics until 2015. ${ }^{9}$ There are around 200 importers and exporters, generating a total of 18,743 country pairs. ${ }^{10}$

Three policy variables describe WTO, PTA and NRTP participation. Data for WTO membership until 2001 come from Tomz, Goldstein and Rivers (2007a); from 2002 onwards, we rely on the WTO website. Tomz et al. use a broad definition of WTO membership that allows for de jure, colonial, de facto and provisional members. This lends itself more naturally to the estimation of NRTP trade effects, as WTO nonmember participants are often NRTP-eligible developing nations that face MFN tariffs just as regular members.

For PTA and NRTP memberships, we rely on the extensive dataset put together by Scott Baier and Jeffrey Bergstrand, available at http://www.nd.edu/jbergstr/, and first used by Baier et al. (2014). The following countries offer preferences under GSP or other types of NRTPs in at least part of the sample period: Australia, Belarus, Canada, Chile, China, members of the European Union, ${ }^{11}$ Iceland, India, Japan, Kazakhstan, Kyrgyzstan, Morocco, South Korea, New Zealand, Norway, Russia, Switzerland, Taiwan, Thailand, Turkey and the United States.

To the best of our knowledge, the trade agreements dataset compiled by Baier and Bergstrand is, by far, the most complete and accurate available. For PTAs, there are other

that gives better access to the American market for firms from Bolivia, Colombia, Ecuador and Peru.

${ }^{8}$ http://www.correlatesofwar.org/data-sets/bilateral-trade. See Barbieri, Keshk and Pollins (2009) for a description of the data.

${ }^{9} \mathrm{http}: / /$ data.imf.org/?sk=9D6028D4-F14A-464C-A2F2-59B2CD424B85. Data downloaded on September $28,2016$.

${ }^{10}$ Correlates of War data come mainly from the IMF Directions of Trade Statistics. Nonetheless, the first is preferable for the earlier period because it largely solves problems in the IMF data, as for example multiple names and spellings for the same country. See the dataset codebook for more details.

${ }^{11}$ In many cases, E.U. members also offered non-reciprocal preferences before joining the single market. 
reliable and relatively complete sources. ${ }^{12}$ For NRTPs, in contrast, most of the sources used in the literature are incomplete and/or inconsistent with each other. For current membership, the WTO does provide a complete and detailed list (http://ptadb.wto.org/), but not for historical membership information. For data up to 2003, the best alternative has been Liu's (2009) codification (available at http://ksuweb.kennesaw.edu/ xliu6/). He draws from all information available directly from UNCTAD's (several years) reports on GSP. However, as mentioned in the introduction, those reports are not published regularly. Sometimes they are published in consecutive years, but during some periods it takes several years before a new report is released. In contrast, the Baier-Bergstrand dataset draws mostly from primary sources, and provides a link to the original treaty whenever there is a change in status. Thus, we believe that the Baier-Bergstrand dataset largely solves this fundamental difficulty for the estimation of the trade effects of NRTPs. As our trade data goes until 2015, we update the Baier-Bergstrand data up to that year. We use original documents from the WTO's PTA database to account for changes in (or the creation of) GSP programs of the following countries: Canada, members of the E.U., Norway, Switzerland and the United States. ${ }^{13}$

In addition, we collect information on twenty seven individual arrangements that offer better-than-GSP preferences. The majority of those schemes was created after the 2000's and many of them coexist with the ordinary GSP programs. They fall into three categories: i) expansions of already existing GSPs with additional preferences often given to LDCs; ii) new non-GSP, LDC-exclusive programs; and iii) preferences to a distinct subset of countries, usually with a limited regional reach. The countries offering such programs are Australia, Canada, Chile, China, members of the E.U., Iceland, India, Japan, Kazakhstan, Korea, Kyrgyzstan, Morocco, New Zealand, Norway, Switzerland, Thailand, Taiwan, Turkey and the U.S. Table A1 in the Appendix lists all programs and their starting dates. $^{14}$

For the definition of Least Developed Countries, which we use to identify heterogeneous

\footnotetext{
${ }^{12}$ For example, De Sousa (2012, data available at http://jdesousa.univ.free.fr/data.htm) and the WTO itself (http://rtais.wto.org).

${ }^{13}$ We also update some information in the Baier-Bergstrand dataset related to unrecorded withdrawals of GSP preferences. Portugal and Spain receiving GSP benefits after 2000 is a clear example. We do so whenever we find solid evidence for the withdrawals.

${ }^{14}$ Data on GSP-LDC and LDC-specific schemes is available at the WTO's PTA database. Information on AGOA and CBI is available at the programs' websites (https://www.trade.gov/agoa/eligibility/index.asp and https://ustr.gov/issue-areas/trade-development/preference-programs/caribbean-basin-initiative-cbi). We do not consider short, temporary suspensions from better-than-GSP programs, both because they are not widespread and, especially, because of their temporary nature.
} 
effects, we follow the United Nations' list of membership and graduations. ${ }^{15}$ Notice that $\mathrm{LDC}$ is a formal denomination given to very poor nations created by the UN using criteria of social development and economic vulnerability.

Figures 1 and 2 illustrate how our dependent variable, bilateral annual imports, varies over time within nonreciprocal trade arrangements. ${ }^{16}$ Figure 1 displays the share of imports coming from NRTP beneficiaries when the importer is the United States, the European Union and other "donor" countries. ${ }^{17}$ One visible common pattern emerges: after a sharp increase in the share of imports from NRTP beneficiaries in the first half of the 1970s (as the main powers implemented their GSPs), a period of steady decline ensued. ${ }^{18}$

There are large and abrupt falls and surges in all import shares. They vary either because of changes in import volumes or in the composition of the beneficiaries' list. Adjustments in the latter are revealing of the design of NRTPs and illustrate one of the main sources of variation in the data beyond NRTP creation: changes in the identity of beneficiaries due to either the formation of "deeper," reciprocal trade agreements or to reforms of the program. Consider the share of U.S. imports from NRTP beneficiaries. It falls over 10 percentage points from 1987 to 1988, when GSP status was removed at once from Bahrain, Bermuda, Brunei Darussalam, Nauru, Hong Kong, South Korea, Panama, Singapore and Taiwan, and by 6 percentage points from 1993 to 1994, when the U.S. granted Mexico wider and deeper preferences under the North American Free Trade Agreement. Similar cases are observed after 2009, with the signature of the U.S.-Peru and U.S.-Colombia FTAs in 2009 and 2012, respectively, and with the suspension of Argentina's benefits in 2012.

In more recent years, donor countries have modified their NRTPs in order to prioritize preferences for poorer nations, notably LDCs. This is the case of a recent revision of the European GSP program in 2014 that lowered the E.U. total import share from NRTP

\footnotetext{
${ }^{15}$ The current list of LDCs and the timeline of countries' graduation are available at https://www.un.org/development/desa/dpad/least-developed-country-category/ldc-graduation.html.

${ }^{16}$ Notice that NRTPs do not necessarily cover all exports of a beneficiary to a "donor" country. In fact, there is much discretion with regard to the depth and width of benefits (see Ornelas, 2016, section 2.1 for a detailed discussion). Shares in figures 1 and 2 are, thus, an upper bound on the trade flows actually enjoying nonreciprocal preferences.

${ }^{17}$ The definition of "European Union" changes according to the membership of the bloc, from its original composition of six countries to its current twenty eight members. For the "Others" series, we use a weighted average of shares of imports coming from NRTP beneficiaries across other countries offering nonreciprocal preferences, using as weights the share of the country in the rest of the world's total imports.

${ }^{18}$ Positive import shares before 1970 refer to the French Empire System of Preferences and to an arrangement between six European countries and selected African states (Yaoundé Convention). In that period, the Baier-Bergstrand database also classifies the Commonwealth PTA between the United Kingdom and its current and former colonies as an NRTP arrangement based on a 1932 document. We do not take the latter into account due to scarce documentation.
} 


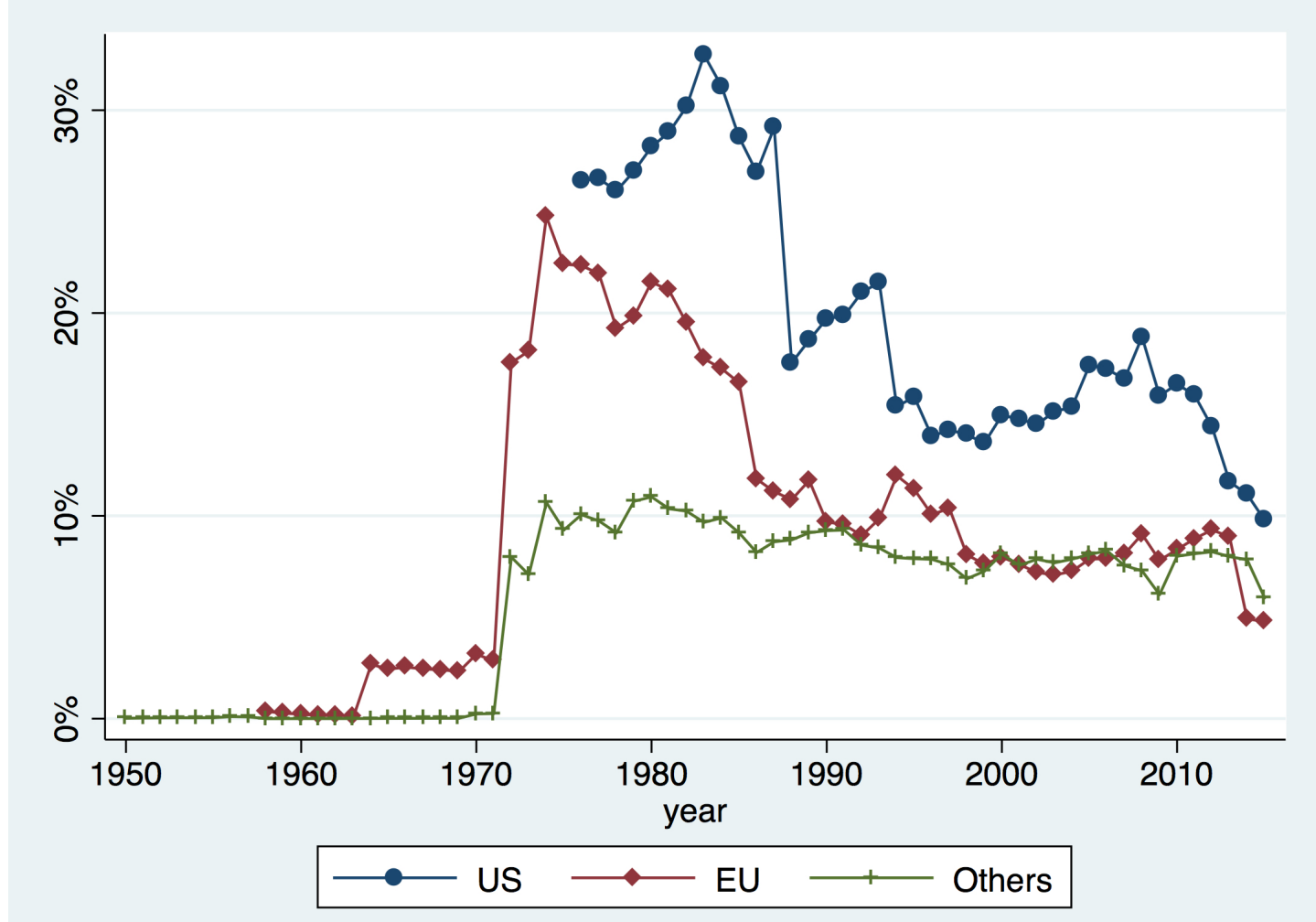

Figure 1: Share of Imports coming from NRTP beneficiaries

beneficiaries by 4 percentage points. The list of eligible countries shrank, large exporters like Argentina, Brazil and Russia lost preferential access, whereas better access was given to those "most in need."

Figure 2 shows instead the proportion of exports of non-LDC developing countries and of LDCs to NRTP donor countries in their overall foreign sales. ${ }^{19}$ A comparison between the two figures makes clear that the preferences tend to be much more meaningful for the countries receiving than for the countries offering them. Now, although again there are multiple reasons for shifts in shares, there is a clear underlying pattern over time. After a sharp increase in the 1970s, when the main NRTP programs were introduced, the shares remained roughly unchanged until around 1990. Since then, the shares have declined steadily for non-LDC beneficiaries, reaching less than $20 \%$ in recent years. The general pattern is not very different for LDC countries until 2010, although for them exports to countries offering NRTPs are more important and the decline starting in 1990 is less acute. In 2010, however, their NRTP export shares jumped around 30 percentage points, due mostly to the creation of China's Duty-Free Treatment for LDCs that year. Since

\footnotetext{
${ }^{19}$ The definition of developing countries is taken from the World Bank.
} 


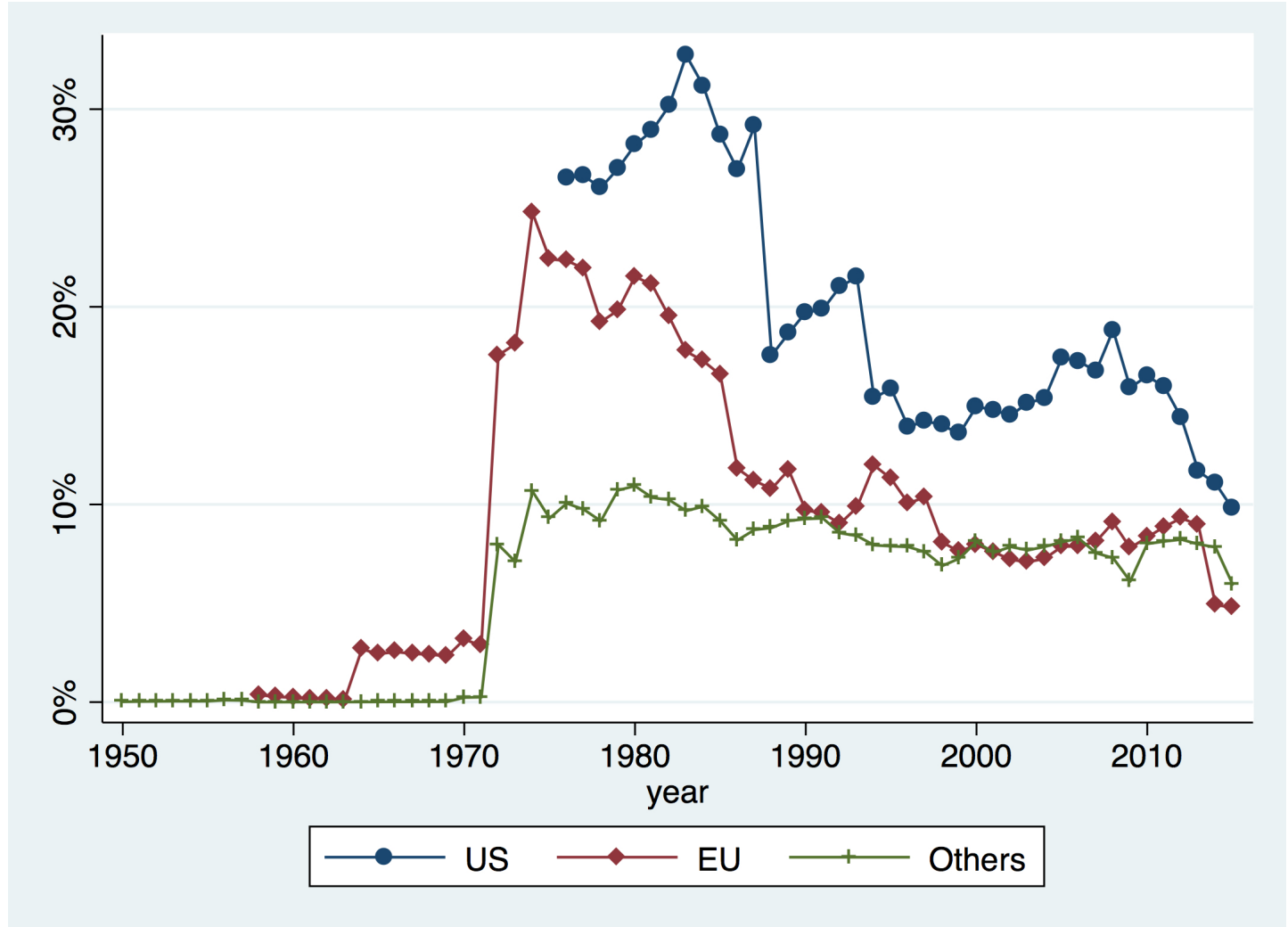

Figure 2: Export Shares to Markets Offering NRTPs

then, the shares of LDC beneficiaries returned to a declining trend, reaching around $60 \%$ in 2015 .

Following most of the literature, we describe participation in different types of trade agreements using dummy variables. Let $m$ be the importer, $x$ the exporter and $t$ the year. Specifically, $P T A_{m x t}=1$ if $m$ and $x$ are members of the same PTA at $t$ and 0 otherwise, and $W T O_{m x t}=1$ if $m$ and $x$ are both WTO members at $t$ and 0 otherwise. In turn, $N R T P_{m x t}=1$ if $m$ offers trade preferences to $x$ through a nonreciprocal trade arrangement at $t$ and 0 otherwise. Observe that, unlike the PTA and WTO dummies, which are bilateral, the $N R T P$ variable is unilateral, as it corresponds to nonreciprocal concessions.

The Baier-Bergstrand database codes trade agreements depending on the level of economic integration. In their taxonomy, which ranges from 1 to 6 in a mutually exclusive way, 1 is assigned to Nonreciprocal Preferential Trade Agreements; 2 to Preferential Trade Arrangements; 3 to Free Trade Areas; 4 to Custom Unions; 5 to Common Markets; and 6 to Economic Unions. Our NRTP variable corresponds to arrangements coded as 1 in the Baier-Bergstrand database, whereas our PTA variable incorporates those coded from 2 to 
6. The NRTP and PTA variables are, therefore, mutually exclusive.

To provide a clearer sense of the 'within' variation that we exploit in our estimations, Table 1 describes the changes over time of the trade agreement variables across country pairs following the description above. For example, if the WTO dummy regarding countries $m$ and $x$ is 0 until 1965 and 1 from that year onwards, the cell under column "WTO/entry" and row "1960s" has an increment of one. The same procedure applies to the cells under columns "PTA" and "NRTP" (entry). For the columns under the "exit" label, we apply the same procedure but for negative changes. Variation in membership is of course crucial to provide power to the estimations. While those changes are not uniform through time, there are meaningful changes in all decades.

Table 1: Changes in main variables

\begin{tabular}{crrrrrr}
\hline Decade & \multicolumn{2}{c}{ NRTP } & \multicolumn{2}{c}{ WTO } & \multicolumn{2}{c}{ PTA } \\
& Entry & Exit & Entry & Exit & Entry & Exit \\
\hline 1950 's & 1 & 0 & 1,314 & 614 & 124 & 0 \\
1960 's & 129 & 0 & 2,343 & 192 & 191 & 30 \\
1970 's & 2,236 & 50 & 1,160 & 234 & 566 & 0 \\
1980 's & 579 & 152 & 1,369 & 0 & 422 & 2 \\
1990 's & 522 & 225 & 4,461 & 2,104 & 1,322 & 157 \\
2000's & 2,476 & 2,096 & 5,663 & 0 & 3,438 & 68 \\
Note: The figures in the last row include changes from 2000 to 2015.
\end{tabular}

As indicated in the column "NRTP/entry," some pre-GSP nonreciprocal arrangements already existed before the 1970's. At that time, European countries granted trade preferences to their overseas recently independent ex-colonies. ${ }^{20}$ In the 1970's, concession of unidirectional preferences became widespread, going beyond former colonial ties. The number of NRTPs soared as special and differential benefits for developing countries became compatible with obligations under the GATT. In the 2000's, the E.U. enlargement led to a similarly massive growth in NRTPs, as new E.U. members automatically adopted previously existing trade policy responsibilities under the European GSP.

The number of nonreciprocal arrangements that have been reversed also spiked recently. As showed in the column "NRTP/exit," after evolving in a steady but mild pace, exits were much more prevalent in the 2000's than in previous decades. Around half of those exits are consequences of reciprocal liberalization. There are not only newly-minted reciprocal agreements between former NRTP donor and beneficiaries, but also newcomers to ongoing

\footnotetext{
${ }^{20}$ The only count under "NRTP/entry" in the 1950's is due to benefits to Cambodia under the French Empire System of Preferences. In the 1960's, counts relate to 18 new African territories receiving trade benefits from former European metropoles inside the Yaoundé Convention.
} 
PTAs replacing previous GSP relationships. An example of the former is the PTA between the U.S., Dominican Republic and other Central American countries in 2006. An example of the latter is Bulgaria's removal of Lebanon's GSP status and concession of preferential treatment under the E.U.-Lebanon PTA after Bulgaria's accession in 2007. The remaining exits are chiefly due to the revision of the European GSP in 2014, when several middleincome countries lost preferential access to the E.U.

Table 1 also shows some seemingly unusual exits from the GATT/WTO in the 1990's. They relate mainly to newly independent territories, which used to receive membership benefits as colonial possessions of contracting parties. Ex-colonies had three options when updating their ties to the GATT. First, become a contracting party themselves using either the same terms and conditions negotiated by the metropole on their behalf or bargaining new ones. ${ }^{21}$ Second, take additional limited time to plan future trade policies and in the meantime let GATT's de facto obligations carry out trade relationships. Third, quit the GATT. Exits from the GATT/WTO relate to the last two options. Their high frequency during the 1990's owns to the then newly created WTO, which no longer allowed for de facto membership and required countries to either accede to the organization or lose benefits. $^{22}$

PTA exits are rare, and happened mainly among former USSR provinces or under very specific situations, like the suspension of the Syria-Turkey PTA in 2011 in the context of the Syrian civil war. In the Appendix we disentangle further the changes indicated in Table 1 to better explain the sources of variation in our main independent variables.

Finally, there is a large share of observations with zero trade flows (44\% of the sample). This is a well-known pattern in the trade gravity literature. Interestingly, as Table 2 shows, there is a significant number of zero-trade-flow observations even when countries are linked through a trade agreement. In particular, there are no trade flows in $18 \%$ of the observations in which countries receive NRTPs. This should not come as a total surprise, since eligibility often follows (inverse) development status criteria. Still, it is an important fact to take into account in the estimations. Observe also that the zeros are especially prevalent when one country is an LDC, but are present even between non-LDC countries.

\footnotetext{
${ }^{21}$ Via Article XXVI:5(c) or Article XXXIII, respectively.

${ }^{22}$ See Tomz, Goldstein and Rivers (2007b) for a more comprehensive discussion of nonmember de facto participation in the GATT/WTO.
} 
Table 2: Observations with zero trade flows

\begin{tabular}{lccc}
\hline \hline Variable & $\begin{array}{c}\text { Var. } 1 \mid \text { Imports }=0 \\
(\mathrm{I})\end{array}$ & $\begin{array}{c}\text { Variable }=1 \\
(\mathrm{II})\end{array}$ & I/II \\
\hline NRTP & 26,166 & 142,194 & $18 \%$ \\
WTO & 339,436 & 888,565 & $38 \%$ \\
PTA & 14,060 & 109,369 & $13 \%$ \\
NRTP $\times$ WTO & 18,598 & 105,972 & $18 \%$ \\
PTA $\times$ WTO & 8,508 & 85,173 & $10 \%$ \\
NRTP $\times$ LDC & 13,997 & 48,769 & $29 \%$ \\
WTO $\times$ LDC & 69,810 & 133,006 & $52 \%$ \\
PTA $\times$ LDC & 7,189 & 17,963 & $40 \%$ \\
NRTP $\times$ WTO $\times$ LDC & 9,116 & 33,721 & $27 \%$ \\
PTA $\times$ WTO $\times$ LDC & 3,750 & 11,735 & $32 \%$ \\
\hline \hline Other Statistics & & & \\
\hline No Trade Preferences $\&$ Imports $=0$ & Observations & $\%$ of Sample \\
\hline \hline
\end{tabular}

\section{Empirical Strategy}

We estimate a structural gravity equation following Head and Mayer (2014). It relates imports by country $m$ from country $x$ in year $t$ to trade agreement variables PT $A_{m x t}$, $W T O_{m x t}$ and NRTP $P_{m x t}$ and theory-consistent gravity controls.

The empirical model contains importer and exporter time-varying fixed effects. Those fixed effects control for the endogenous "multilateral resistance" suggested by Anderson and Van Wincoop (2003) in a panel context, as proposed by Baier and Bergstrand (2007). Furthermore, we include (time-invariant) country-pair fixed effects to account for unobserved bilateral heterogeneity and minimize the endogeneity of trade agreements, as first suggested by Baldwin and Taglioni (2006) and Baier and Bergstrand (2007).

The country-pair fixed effects imply that we are estimating the "within" effect, or 
how the formation (or the dissolution) of an NRTP affects the imports of the country granting the preferences from the country receiving them. Collectively, the three sets of fixed-effects entail a triple-difference strategy. It first compares donors and beneficiaries' average trade levels inside and outside NRTPs' life-span. It then subtracts simultaneous average growth of imports of donors and exports of beneficiaries with respect to thirdcountries. As indicated in section 1.1, only recently authors have started to use the full set of fixed effects to control for multilateral resistance and for unobserved heterogeneity when estimating the trade effects of NRTPs. As Head and Mayer (2014) demonstrate, such omissions can matter significantly in the estimation of the impact of trade policy variables. For NRTPs in particular, together with the data problems discussed earlier, this has been an important source of the conflicting estimates in the literature.

Observe that most of the usual controls included in gravity estimations (such as GDP, distance, colonial status and common language) are either country-specific or time-invariant. Consequently, their impacts are absorbed into the fixed effects. Since they are not of particular interest here, it is preferable to use the large set of fixed effects just described to control for all observable and unobservable trade costs in their respective dimensions.

While there are concerns about bilateral bias in the estimation of PTA trade effects, our set of fixed effects is able to neutralize important potential sources of endogeneity affecting NRTP estimates. As pointed out by Baier and Bergstrand (2007), selection into PTAs may be correlated with bilateral trade volumes. So far, the existing literature has relied on country-pair fixed effects to alleviate those potential endogeneity issues, but it cannot take into account biases stemming from a time-varying dimension. ${ }^{23}$ Selection into NRTPs, by contrast, typically reflects donors' unilateral decisions to start a general program of preferences whose list of beneficiaries tends to follow an income criterion. Sources of potential unilateral or bilateral biases are, thus, reasonably attenuated by our large set of fixed effects. ${ }^{24}$

Altogether, our benchmark specification is given by

$$
M_{m x t}=\exp \left(\beta_{1} N R T P_{m x t}+\beta_{2} W T O_{m x t}+\beta_{3} P T A_{m x t}+\gamma_{m t}+\phi_{x t}+\alpha_{m x}\right)+\epsilon_{m x t},
$$

where $M_{m x t}$ are imports; $N R T P_{m x t}, W T O_{m x t}$ and $P T A_{m x t}$ are the trade agreement dum-

\footnotetext{
${ }^{23}$ See Limao (2016, section 3.2) for a thorough discussion of this topic.

${ }^{24}$ In some GSPs, like the American, eligible countries need to request entry in the program. While this may raise concerns about selection, the vast majority of eligible countries do request entry, so in practice selection is not a particularly worrying issue.
} 
mies discussed above; $\gamma_{m t}$ and $\phi_{x t}$ are the importer and exporter time-varying fixed effects, respectively; $\alpha_{m x}$ is the country-pair fixed effect; and $\epsilon_{m x t}$ is an error term.

We estimate this gravity equation with high-dimensional fixed effects using both PPML and OLS. ${ }^{25}$ There are considerable differences between the two estimation procedures, as showed by Santos-Silva and Tenreyro (2006). Besides heteroskedasticity issues, a key difference is the inclusion of zero trade flows in the PPML regression, but not in the OLS specification. This matters because, as showed in Table 2, NRTPs between countries that do not trade with each other are common. For that reason, we focus on the PPML specification, but report results with an OLS specification and, for comparison purposes, also with PPML but with the sample used in the OLS specification (i.e., excluding observations with zero trade flows). We correct standard errors by allowing shocks to have a pattern of interdependence across country-pairs, i.e., there are clusters for different combinations of importers and exporters.

As discussed above, a central ingredient of our analysis is the distinction between the effects of NRTPs for LDCs and other beneficiary countries. Given the differences in economic structure, the same preferences may have distinct consequences for the exports of LDCs and of other developing economies. But often the scope and depth of preferences are also different. For example, all the main GSP donor countries currently have one or more sub-schemes in which better market access is offered, e.g. the U.S.'s AGOA and the E.U.'s Everything but Arms. Those sub-schemes often include LDCs as beneficiaries, although in general being an LDC is neither a necessary nor a sufficient condition for eligibility into those better-than-GSP programs. In fact, currently all LDCs have better-than-GSP treatment in the American and European markets.

We capture the differential effects for LDCs by interacting all the trade policy variables with an $L D C_{x t}$ dummy, which is unity if the exporter country $x$ is formally defined as an LDC in year $t$. To investigate whether potential differential effects for LDCs are due to their LDC status (and everything that encompasses) or to especially generous preferences, in some specifications we interact a dummy that captures only better-than-GSP preferences with the other trade policy indicators.

We carry out the analysis at the year level. This contrasts with a sizable share of the literature, which uses data every four or five years. Since the changes in the main independent variables are codified annually, we believe it is more appropriate to keep the

\footnotetext{
${ }^{25}$ For the PPML estimation, we employ the ppml_panel_sg Stata command used by Larch et al. (2017). For the OLS estimation, we follow the methodology developed by Guimaraes and Portugal (2010).
} 
analysis at the same time horizon.

\section{Results}

\subsection{Benchmark}

Table 3 shows the benchmark results for the impact of NRTPs on country-pair trade flows, controlling for WTO and PTA membership and including the large set of fixed effects discussed above. They vary significantly across econometric specifications. NRTPs have either a small positive average effect on trade flows (OLS), zero average impact (PPML with OLS sample) or negative (PPML with full sample). Such instability of the NRTP coefficient may be disconcerting but is not surprising; in fact, it is consistent with the conflicting findings in the literature.

Table 3: Average Trade Policy Effects

\begin{tabular}{|c|c|c|c|}
\hline & $\begin{array}{c}\text { OLS } \\
(1)\end{array}$ & $\begin{array}{c}\mathrm{PPML}^{\dagger} \\
(2)\end{array}$ & $\begin{array}{c}\text { PPML } \\
(3)\end{array}$ \\
\hline NRTP & $\begin{array}{c}0.081^{* * *} \\
(0.027)\end{array}$ & $\begin{array}{c}0.005 \\
(0.019)\end{array}$ & $\begin{array}{c}-0.034^{*} \\
(0.019)\end{array}$ \\
\hline WTO & $\begin{array}{c}0.098^{* *} \\
(0.040)\end{array}$ & $\begin{array}{c}0.191^{* *} \\
(0.079)\end{array}$ & $\begin{array}{c}0.165^{* *} \\
(0.079)\end{array}$ \\
\hline PTA & $\begin{array}{c}0.496^{* * *} \\
(0.026)\end{array}$ & $\begin{array}{c}0.399 * * * \\
(0.021)\end{array}$ & $\begin{array}{c}0.386^{* * *} \\
(0.020)\end{array}$ \\
\hline Observations & 852,052 & 852,052 & $1,431,430$ \\
\hline \multicolumn{4}{|c|}{$\begin{array}{l}\text { Notes: Standard errors in parentheses. }{ }^{*},{ }^{* *} \text { and }{ }^{* * *} \\
\text { indicate statistical significance at the } 10 \%, 5 \% \text { and } 1 \% \\
\text { levels, respectively. }{ }^{\dagger}: \text { PPML regression with same } \\
\text { sample used in OLS regression. All regressions include } \\
\text { importer and exporter time-varying fixed effects and } \\
\text { symmetric country-pair fixed effects. Standard errors } \\
\text { are symmetrically clustered by country-pairs. }\end{array}$} \\
\hline
\end{tabular}

The estimates of the WTO trade effect are large, statistically significant and robust across specifications. The PTA trade effect follows the same pattern, but with a much larger magnitude. Size and statistical significance of PTA estimates are in line with the received literature, as summarized by Head and Mayer (2014) and Limao (2016). Observe also, comparing columns 2 and 3, that disregarding the zero-trade-flow observations tends 
to overestimate the trade effects of all types of trade agreements, as it neglects all cases when a trade policy link is formed but trade remains absent-and such cases are not uncommon. That neglect is especially critical for the estimation of the NRTP coefficient.

Now, a concern about our methodology, which also affects most of the related literature, is that changes in trade flows may induce the concession of NRTPs. For example, preferences may be offered to a country when imports from that country are rising. Or instead, preferences may be suspended if preferential imports from a beneficiary rise too fast. Naturally, such endogeneity of our key trade policy variable would affect the estimation of its effects.

Ideally, one would like to have truly exogenous variation in the concession of NRTPs, or appropriate instruments for them. To our knowledge, such indisputable exogenous variation for the estimation of the effects of trade agreements (of any kind) has not been found yet. We can, nevertheless, investigate whether there are clear signs of changes in bilateral trade flows just before concessions are offered or withdrawn, to infer the potential importance of endogenous motives behind them.

Figure 3 plots the results from a set of PPML regressions investigating those possibilities, where we add two extra dummies to the baseline regression equation (1): one is unity for the $T$ years just before the establishment of a NRTP, while the other is unity for the $T$ years just before its withdrawal, with $T=1, \ldots, 5$ varying across specifications. The "Pre-Trend" dummy captures changes in trade levels that could explain future concession of NRTPs. The "Last Years" dummy captures what happens to trade levels just before NRTPs are withdrawn. ${ }^{26}$

The NRTP estimates are very stable across the different specifications, as are the WTO and PTA estimates. Meanwhile, there is no evidence of pre-trends and no special change in the pattern of bilateral trade flows just before concessions are withdrawn. We interpret those results as suggestive that changes in trade flows are not key determinants of the decision to offer or remove NRTPs.

\subsection{Heterogeneous Effects}

There is significant heterogeneity hidden behind the general denomination of nonreciprocal trade arrangements. We start to investigate this in Table 4.

First (columns 1 to 3), we interact the NRTP and PTA indicators with the WTO

\footnotetext{
${ }^{26}$ Table A2 in the Appendix has the complete set of results, including an OLS specification.
} 


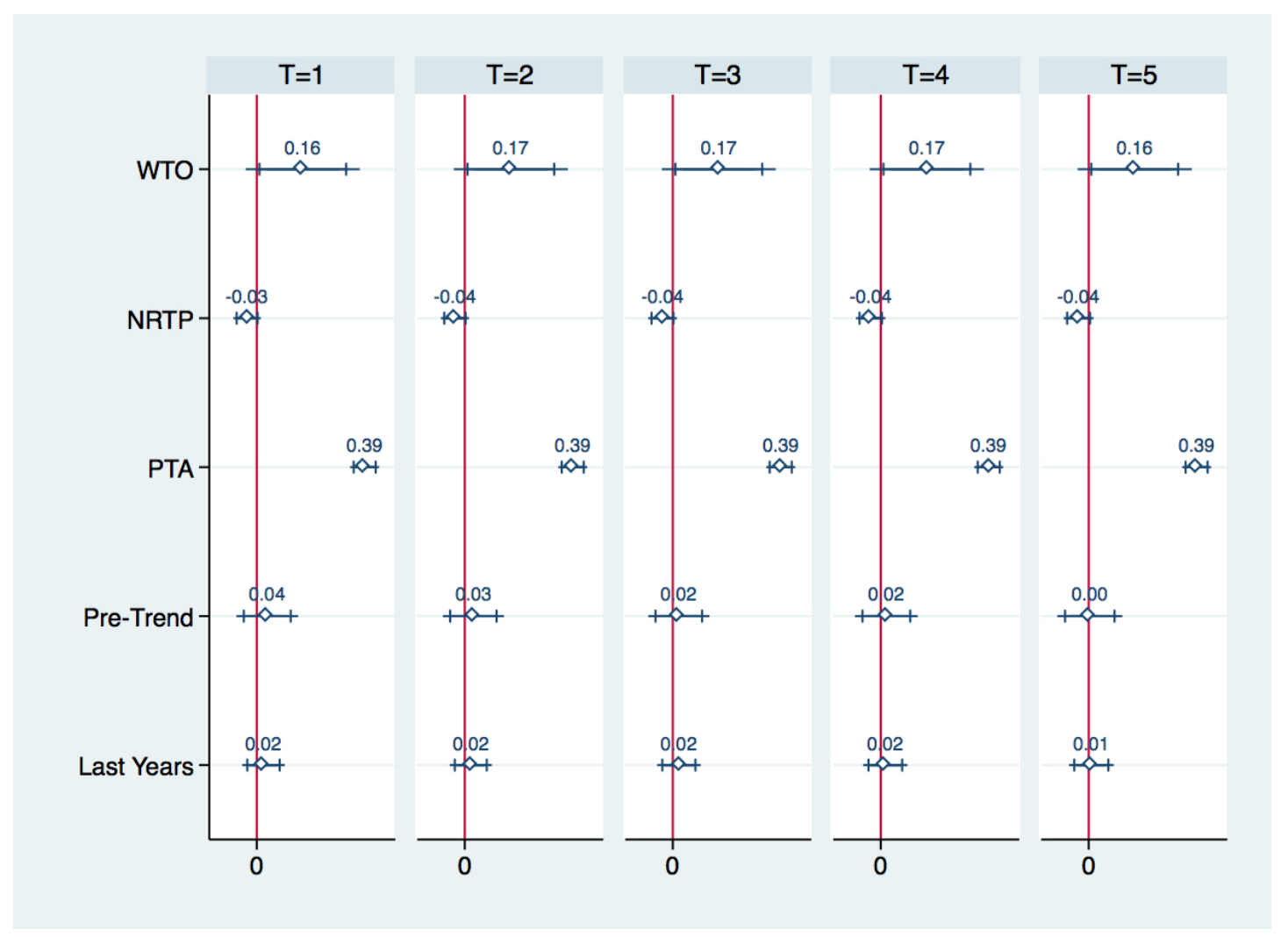

Figure 3: Pre-Trends and Last Years

dummy to see whether the absence of a robust NRTP effect hinges on participation in the WTO. Results show that the NRTP trade effect is actually positive and highly significant for non-WTO members (first row of the table, columns 1-3). At the bottom of Table 4 we then compute the effect of NRTP preferences when the pair of countries are already WTO members. The results follow the same pattern of the benchmark regression: no sign that NRTPs foster beneficiaries' exports. Hence, the estimates in regressions 1-3 suggest that nonreciprocal preferences may be redundant if a country already enjoys MFN treatment and other benefits of WTO membership. ${ }^{27}$

\footnotetext{
${ }^{27}$ Another interesting result in columns 1-3 is the strongly negative interaction between WTO and PTA memberships in the PPML specifications (although not in the OLS specification), suggesting substitutability between those two types of trade agreements. It suggests that, once countries have secured access to each other's markets under MFN tariffs, PTA preferences become less effective in stimulating trade. This result mirrors a finding by Liu (2016) about the growth effects of PTAs.
} 
Table 4: WTO and LDCs

\begin{tabular}{|c|c|c|c|c|c|c|}
\hline & \multicolumn{3}{|c|}{ WTO } & \multicolumn{3}{|c|}{ LDCs } \\
\hline & $\begin{array}{l}\text { OLS } \\
(1)\end{array}$ & $\begin{array}{l}\mathrm{PPML}^{\dagger} \\
(2) \\
\end{array}$ & $\begin{array}{l}\text { PPML } \\
(3) \\
\end{array}$ & $\begin{array}{l}\text { OLS } \\
(4)\end{array}$ & $\begin{array}{c}\mathrm{PPML}^{\dagger} \\
(5) \\
\end{array}$ & $\begin{array}{c}\text { PPML } \\
(6) \\
\end{array}$ \\
\hline NRTP & $\begin{array}{c}0.104^{* *} \\
(0.042)\end{array}$ & $\begin{array}{c}0.214^{* * *} \\
(0.040)\end{array}$ & $\begin{array}{c}0.186^{* * *} \\
(0.040)\end{array}$ & $\begin{array}{c}0.010 \\
(0.028)\end{array}$ & $\begin{array}{l}-0.016 \\
(0.020)\end{array}$ & $\begin{array}{c}-0.059^{* * *} \\
(0.019)\end{array}$ \\
\hline $\mathrm{NRTP} \times \mathrm{WTO}$ & $\begin{array}{l}-0.025 \\
(0.043)\end{array}$ & $\begin{array}{c}-0.278^{* * *} \\
(0.047)\end{array}$ & $\begin{array}{c}-0.289^{* * *} \\
(0.047)\end{array}$ & & & \\
\hline $\mathrm{NRTP} \times \mathrm{LDC}$ & & & & $\begin{array}{c}0.281^{* * *} \\
(0.050)\end{array}$ & $\begin{array}{c}0.420^{* * *} \\
(0.055)\end{array}$ & $\begin{array}{c}0.528^{* * *} \\
(0.060)\end{array}$ \\
\hline WTO & $\begin{array}{c}0.096^{* *} \\
(0.040)\end{array}$ & $\begin{array}{c}0.266^{* * *} \\
(0.082)\end{array}$ & $\begin{array}{c}0.238^{* * *} \\
(0.082)\end{array}$ & $\begin{array}{c}0.098^{* *} \\
(0.040)\end{array}$ & $\begin{array}{c}0.189^{* *} \\
(0.079)\end{array}$ & $\begin{array}{c}0.162^{* *} \\
(0.079)\end{array}$ \\
\hline $\mathrm{WTO} \times \mathrm{LDC}$ & & & & $\begin{array}{c}0.113 \\
(0.079)\end{array}$ & $\begin{array}{c}0.469^{* * *} \\
(0.123)\end{array}$ & $\begin{array}{c}0.492^{* * *} \\
(0.131)\end{array}$ \\
\hline PTA & $\begin{array}{c}0.418^{* * *} \\
(0.047)\end{array}$ & $\begin{array}{c}0.600^{* * *} \\
(0.034)\end{array}$ & $\begin{array}{c}0.552^{* * *} \\
(0.036)\end{array}$ & $\begin{array}{c}0.513^{* * *} \\
(0.027)\end{array}$ & $\begin{array}{c}0.397^{* * * *} \\
(0.021)\end{array}$ & $\begin{array}{c}0.383^{* * *} \\
(0.020)\end{array}$ \\
\hline $\mathrm{PTA} \times \mathrm{WTO}$ & $\begin{array}{c}0.100^{* *} \\
(0.049)\end{array}$ & $\begin{array}{c}-0.237^{* * *} \\
(0.035)\end{array}$ & $\begin{array}{c}-0.197^{* * *} \\
(0.036)\end{array}$ & & & \\
\hline $\mathrm{PTA} \times \mathrm{LDC}$ & & & & $\begin{array}{c}-0.160^{*} \\
(0.083)\end{array}$ & $\begin{array}{c}0.021 \\
(0.132)\end{array}$ & $\begin{array}{c}0.130 \\
(0.141)\end{array}$ \\
\hline
\end{tabular}

NRTPs for WTO members

$\mathrm{NRTP}+\mathrm{NRTP} \times \mathrm{WTO}$

$0.079^{* * *} \quad-0.064^{* * *} \quad-0.104^{* * *}$

$(0.029) \quad(0.022) \quad(0.022)$

NRTPs for LDCs

$0.291^{* * *} \quad 0.405^{* * *} \quad 0.469^{* * *}$

NRTP + NRTP $\times$ LDC

$(0.049) \quad(0.054) \quad(0.058)$

\begin{tabular}{lllllll}
\hline Observations & 852,052 & 852,052 & $1,431,430$ & 852,052 & 852,052 & $1,431,430$ \\
\hline
\end{tabular}

Notes: Standard errors in parentheses. ${ }^{*},{ }^{* *}$ and ${ }^{* * *}$ indicate statistical significance at the $10 \%$,

$5 \%$ and $1 \%$ levels, respectively. ${ }^{\dagger}$ : PPML regression with same sample used in OLS regression.

All regressions include importer and exporter time-varying country fixed effects and symmetric country-pair fixed effects. Standard errors are symmetrically clustered by country-pairs.

Second (columns 4 to 6 ), we interact the trade agreement variables with an LDCexporter indicator to investigate heterogeneities within and across trade arrangements. Observe that the LDC-NRTP interaction captures not only the differential impact of general arrangements like the GSP on very poor economies, but also the effects of more generous sub-arrangements designed specifically for them. The estimates reveal that the 
effects of NRTPs for non-LDC beneficiaries are indeed small (and unstable across specifications). We compute the trade effects for LDC exporters at the bottom of Table 4. For them, NRTPs boost trade strongly, with estimates that are statistically significant and stable across specifications. We also observe larger effects for WTO membership for LDCs in the PPML regressions.

The results in Table 4 therefore suggest that NRTPs have substantial positive effects on the exports of countries that are either outsiders in the world trading system or among the world's most impoverished nations. In Table 5 we then explore the interplay of those two findings by allowing for simultaneous interactions of the NRTP and PTA variables with an LDC-exporter indicator and the WTO dummy.

The results show that the picture portrayed in Table 4 is incomplete. Table 5 reveals that NRTPs are especially effective in promoting the exports of beneficiaries when they are LDCs who are already WTO members, as the last row of the table indicates. That is, the strong NRTP effect for LDCs in Table 4 is driven largely by LDCs that belong to the WTO. NRTPs are also effective (although not as much) in boosting foreign sales of beneficiary countries that are not LDCs but remain at the fringes of the multilateral trading system, as the first row of the table indicates. That is, the strong NRTP effect for WTO nonmembers in Table 4 is driven mainly by not-so-poor developing countries.

Hence, our findings reveal that participation in the multilateral trading system matters for the effectiveness of nonreciprocal preferences, and does so differently depending on the degree of development of the beneficiary country. Without a structural model to provide precise meaning to our estimates, any interpretation is necessarily tentative. But a possibility is that very poor economies may not have the capabilities to re-allocate their resources in order to take advantage of tariff preferences in advanced markets. As WTO accession requires some degree of economic reforms that induce fragile economies to use their economic resources more efficiently, WTO membership could provide such countries the means to benefit from NRTPs. Indeed, in the next subsection we provide suggestive evidence that 'institutional quality,' broadly defined, may be the key to explain why NRTPs help LDCs to export only when they join the WTO. ${ }^{28}$

\footnotetext{
${ }^{28}$ On a similar point, note that, in the absence of NRTPs and PTAs, WTO membership promotes trade for all counties, but does so much more strongly for LDCs, presumably because of the economic reforms associated with WTO accession.
} 
Table 5: WTO and LDC Interactions

\begin{tabular}{|c|c|c|c|}
\hline & $\begin{array}{c}\text { OLS } \\
(1) \\
\end{array}$ & $\begin{array}{c}\mathrm{PPML}^{\dagger} \\
(2)\end{array}$ & $\begin{array}{c}\text { PPML } \\
(3) \\
\end{array}$ \\
\hline NRTP & $\begin{array}{c}0.054 \\
(0.046)\end{array}$ & $\begin{array}{c}0.209^{* * *} \\
(0.042)\end{array}$ & $\begin{array}{c}0.178^{* * *} \\
(0.041)\end{array}$ \\
\hline $\mathrm{NRTP} \times \mathrm{LDC}$ & $\begin{array}{c}0.181^{* *} \\
(0.087)\end{array}$ & $\begin{array}{l}-0.130 \\
(0.088)\end{array}$ & $\begin{array}{l}-0.017 \\
(0.094)\end{array}$ \\
\hline $\mathrm{NRTP} \times \mathrm{WTO}$ & $\begin{array}{c}-0.051 \\
(0.047)\end{array}$ & $\begin{array}{c}-0.300^{* * *} \\
(0.049)\end{array}$ & $\begin{array}{c}-0.312^{* * *} \\
(0.050)\end{array}$ \\
\hline $\mathrm{NRTP} \times \mathrm{LDC} \times \mathrm{WTO}$ & $\begin{array}{c}0.134 \\
(0.099)\end{array}$ & $\begin{array}{c}0.721^{* * *} \\
(0.108)\end{array}$ & $\begin{array}{c}0.706^{* * *} \\
(0.116)\end{array}$ \\
\hline WTO & $\begin{array}{c}0.097^{* *} \\
(0.040)\end{array}$ & $\begin{array}{c}0.266^{* * *} \\
(0.082)\end{array}$ & $\begin{array}{c}0.238^{* * *} \\
(0.082)\end{array}$ \\
\hline $\mathrm{WTO} \times \mathrm{LDC}$ & $\begin{array}{c}0.106 \\
(0.081)\end{array}$ & $\begin{array}{c}0.332^{* * *} \\
(0.127)\end{array}$ & $\begin{array}{c}0.381^{* * *} \\
(0.136)\end{array}$ \\
\hline PTA & $\begin{array}{c}0.428^{* * *} \\
(0.050)\end{array}$ & $\begin{array}{c}0.597 * * * \\
(0.034)\end{array}$ & $\begin{array}{c}0.546^{* * *} \\
(0.037)\end{array}$ \\
\hline $\mathrm{PTA} \times \mathrm{LDC}$ & $\begin{array}{l}-0.067 \\
(0.140)\end{array}$ & $\begin{array}{c}0.234^{* *} \\
(0.106)\end{array}$ & $\begin{array}{c}0.340^{* *} \\
(0.160)\end{array}$ \\
\hline $\mathrm{PTA} \times \mathrm{WTO}$ & $\begin{array}{c}0.107^{* *} \\
(0.052)\end{array}$ & $\begin{array}{c}-0.234^{* * *} \\
(0.035)\end{array}$ & $\begin{array}{c}-0.194^{* * *} \\
(0.037)\end{array}$ \\
\hline $\mathrm{PTA} \times \mathrm{WTO} \times \mathrm{LDC}$ & $\begin{array}{l}-0.115 \\
(0.159)\end{array}$ & $\begin{array}{l}-0.159 \\
(0.184)\end{array}$ & $\begin{array}{l}-0.181 \\
(0.212)\end{array}$ \\
\hline $\begin{array}{l}\text { NRTPs for LDC WTO nonmembers } \\
\text { NRTP + NRTP } \times \text { LDC }\end{array}$ & $\begin{array}{c}0.234^{* * *} \\
(0.079)\end{array}$ & $\begin{array}{c}0.079 \\
(0.079)\end{array}$ & $\begin{array}{l}0.161^{*} \\
(0.086)\end{array}$ \\
\hline $\begin{array}{l}\text { NRTPs for non-LDC WTO members } \\
\text { NRTP + NRTP } \times \text { WTO }\end{array}$ & $\begin{array}{c}0.002 \\
(0.030)\end{array}$ & $\begin{array}{c}-0.090^{* * *} \\
(0.022)\end{array}$ & $\begin{array}{c}-0.133^{* * *} \\
(0.022)\end{array}$ \\
\hline $\begin{array}{l}\text { NRTPs for LDC WTO members } \\
\text { (NRTP + NRTP } \times \text { LDC + NRTP } \times \text { WTO } \\
+ \text { NRTP } \times \text { LDC } \times \text { WTO) }\end{array}$ & $\begin{array}{c}0.317^{* * *} \\
(0.056)\end{array}$ & $\begin{array}{c}0.501^{* * *} \\
(0.063)\end{array}$ & $\begin{array}{c}0.556^{* * *} \\
(0.070)\end{array}$ \\
\hline Observations & 852,052 & 852,052 & $1,431,430$ \\
\hline
\end{tabular}

Notes: Standard errors in parentheses. ${ }^{*},{ }^{* *}$ and ${ }^{* * *}$ indicate statistical significance at the $10 \%$, $5 \%$ and $1 \%$ levels, respectively. ${ }^{\dagger}:$ PPML regression with same sample used in OLS regression. All regressions include importer and exporter time-varying country fixed effects and symmetric country-pair fixed effects. Standard errors are symmetrically clustered by country-pairs. 
Conversely, that distinction is not as important for non-LDC developing countries. With the focus of NRTPs on (often limited and insecure) tariff reductions, nonreciprocal preferential access to larger markets are useful for them while they face the possibility of higher-than-MFN tariffs, but no longer once they become members of the WTO and obtain permanent access to developed markets through their relatively low MFN rates.

\subsection{Robustness and Extensions}

In this subsection, we evaluate several robustness checks and extensions of our main analysis. Specifically, we consider: (1) whether programs that offer wider and deeper preferential access than GSP are the main drivers of our results; (2) whether our findings hinge on the definition of WTO membership including de facto association; (3) whether the results reflect specific periods of our sample or apply more generally; (4) the factors that could help rationalize the heterogeneous results for LDCs; (5) additional robustness checks.

\subsubsection{Better-than-GSP Arrangements}

The main system of nonreciprocal preferences worldwide is GSP, but several countries offer other programs that provide better market access than GSP to specific groups of countries. It is therefore possible that the differential NRTP trade effects across types of countries reflect simply the different scope of preferences across them.

To investigate the effects of NRTPs that offer better market access than GSP, we construct a BetterThanGSP indicator to identify the pairs of countries for which such preferences exist. Observe that BetterThanGSP $P_{m x t}=1$ implies $N R T P_{m x t}=1$, but the reverse is not true. Hence, one should interpret the BetterThan GSP coefficient as the effect of enjoying better preferential access relative to GSP. We add the BetterThanGSP dummy and its interactions with the WTO and LDC indicators to the specification of Table 5.

Table 6 shows the total effects. ${ }^{29}$ The NRTP trade effects are qualitatively unchanged: they boost exports of non-LDC WTO nonmembers and especially of LDCs that are WTO members. Moreover, both effects are larger under better-than-GSP preferences, particularly so for LDC WTO members. Those additional effects are sensible, since better-thanGSP programs are designed for that purpose. For the other two sets of countries, non-LDC WTO members and LDC WTO nonmembers, there is no clear evidence of positive trade effects.

\footnotetext{
${ }^{29}$ Table A3 in the Appendix shows the complete set of results for the OLS and PPML specifications.
} 
Table 6: NRTPs, Better-than-GSP, LDCs and WTO membership

\begin{tabular}{|c|c|c|c|}
\hline & $\begin{array}{c}\text { OLS } \\
(1)\end{array}$ & $\begin{array}{c}\mathrm{PPML}^{\dagger} \\
(2)\end{array}$ & $\begin{array}{c}\text { PPML } \\
(3)\end{array}$ \\
\hline NRTPs for non-LDC WTO nonmembers ${ }^{a}$ & $\begin{array}{c}0.040 \\
(0.047)\end{array}$ & $\begin{array}{c}0.179 * * * \\
(0.041)\end{array}$ & $\begin{array}{c}0.210^{* * *} \\
(0.042)\end{array}$ \\
\hline NRTPs for LDC WTO nonmembers ${ }^{b}$ & $\begin{array}{c}0.229^{* * *} \\
(0.081)\end{array}$ & $\begin{array}{c}0.082 \\
(0.157)\end{array}$ & $\begin{array}{c}0.142 \\
(0.151)\end{array}$ \\
\hline NRTPs for non-LDC WTO members ${ }^{c}$ & $\begin{array}{c}0.017 \\
(0.031)\end{array}$ & $\begin{array}{c}-0.081^{* * *} \\
(0.023)\end{array}$ & $\begin{array}{c}-0.123^{* * *} \\
(0.022)\end{array}$ \\
\hline NRTPs for LDC WTO members ${ }^{d}$ & $\begin{array}{c}0.383^{* * *} \\
(0.062)\end{array}$ & $\begin{array}{c}0.388^{* * *} \\
(0.085)\end{array}$ & $\begin{array}{c}0.532^{* * *} \\
(0.088)\end{array}$ \\
\hline Better-than-GSP scheme for non-LDC WTO nonmembers ${ }^{e}$ & $\begin{array}{c}0.466^{* * *} \\
(0.163)\end{array}$ & $\begin{array}{c}0.417^{*} \\
(0.226)\end{array}$ & $\begin{array}{l}0.394^{*} \\
(0.239)\end{array}$ \\
\hline Better-than-GSP scheme for LDC WTO nonmembers ${ }^{f}$ & $\begin{array}{c}0.237^{* *} \\
(0.111)\end{array}$ & $\begin{array}{c}0.075 \\
(0.100)\end{array}$ & $\begin{array}{c}0.168 \\
(0.111)\end{array}$ \\
\hline Better-than-GSP scheme for non-LDC WTO members ${ }^{g}$ & $\begin{array}{c}-0.130 * * \\
(0.065)\end{array}$ & $\begin{array}{c}-0.253^{* * *} \\
(0.061)\end{array}$ & $\begin{array}{c}-0.197^{* * *} \\
(0.058)\end{array}$ \\
\hline Better-than-GSP scheme for LDC WTO members ${ }^{h}$ & $\begin{array}{c}0.258^{* * *} \\
(0.069)\end{array}$ & $\begin{array}{c}0.519^{* * *} \\
(0.067)\end{array}$ & $\begin{array}{c}0.560^{* * *} \\
(0.076)\end{array}$ \\
\hline Observations & 852,052 & 852,052 & $1,431,430$ \\
\hline
\end{tabular}

Notes: Standard errors in parentheses. ${ }^{*},{ }^{*}$ and ${ }^{* * *}$ indicate statistical significance at the $10 \%$, $5 \%$ and $1 \%$ levels, respectively. All regressions include importer and exporter time-varying country fixed effects and symmetric country-pair fixed effects. Standard errors are symmetrically clustered by country-pairs. ${ }^{\dagger} \mathrm{PPML}$ regression with same sample used in OLS regression.

Total effects are given by the sum of the estimates of the following coefficients: a: NRTP; b: NRTP+NRTP*LDC; c: NRTP+NRTP*WTO; d: NRTP+NRTP*LDC+ NRTP*WTO +NRTP*LDC*WTO; e: NRTP+BetterthanGSP; f: NRTP+NRTP*LDC+BetterthanGSP+ BetterthanGSP*LDC; g: NRTP+NRTP*WTO+BetterthanGSP + BetterthanGSP*WTO; h: NRTP+NRTP*LDC*WTO+NRTP*WTO+NRTP*LDC+BetterthanGSP+

BetterthanGSP*LDC+BetterthanGSP*WTO+BetterthanGSP*LDC*WTO.

Hence, this analysis shows that larger/wider preferential access tends to boost the export impact of 'regular' NRTPs. However, the extra gains remain restricted to the groups of countries that already benefit from the regular NRTPs-non-LDC outside the WTO and, especially, LDCs that are WTO members.

\subsubsection{WTO Formal Membership}

As pointed out in section 2, following Tomz et al.'a (2007a), we use a definition for WTO membership that encompasses de jure, colonial, de facto and provisional members. Such 
a distinction affects chiefly developing economies, which are the beneficiaries of NRTPs. Hence, while Tomz et al.'s seems the most appropriate definition in our context, we should examine whether it is the main driver of our results.

Accordingly, we run the same set of regressions as in Table 5, but changing the definition of the WTO variable. Now, $W T O_{m x t}$ is unity only when $m$ and $x$ are both formal members of the WTO. This definition comprises original/founding members of the GATT, countries that joined the GATT through Articles XXXIII and XXVI:5(c), and those that joined the WTO. As the results in Table 7 show, the trade effects of NRTPs are virtually unchanged when we use the formal definition of WTO membership: NRTPs promote exports of beneficiaries either when they are LDCs within the WTO or non-LDCs outside the WTO, but not otherwise. ${ }^{30}$

\subsubsection{Heterogeneous Effects Over Time}

As observed in Table 2, developing countries' entries and exits in lists of NRTP beneficiaries are not spread evenly over time. Moreover, the value of preferences may also vary with time. In fact, trade between NRTP partners was relatively more important in the 1970's and 1980's (Figure 1). A concern is that our findings may be restricted to a specific period.

To investigate that possibility, we decompose the heterogeneous average trade effects related to LDCs and WTO membership into different decades. We use the specification in Table 5, but further interacting the NRTP, WTO and LDC variables with indicators for different decades (1970's to the 2000's). Figure 4 plots coefficients, $99 \%$ and $95 \%$ confidence intervals from a PPML regression for the total effect for each subset of countries. ${ }^{31}$ Overall, the results point to a decrease in the trade impact of nonreciprocal preferences over time. Part of the reason may be the level of MFN rates, which were significantly higher in the 1970's and 1980's than they are more recently. As preferential margins have fallen, their impact may have fallen accordingly. That general trend notwithstanding, there are important distinctions in each group.

\footnotetext{
${ }^{30}$ There is one interesting difference between the results of tables 5 and 7 . Using the formal definition of membership, in the absence of NRTPs and PTAs, WTO membership has no clear effect on trade volumes, except for LDCs. This illustrates the point made by Tomz et al. (2007a) that accounting for de facto membership is critical for estimating the WTO trade effect.

${ }^{31}$ Diamonds are point estimates, the horizontal lines delimit $99 \%$ confidence intervals, and the shorter segments define $95 \%$ confidence intervals. As in Table 2, the indicator for the 2000's comprehends years between 2000 until 2015. Base levels refer to years before 1970. As in Table 5, the total effect for each subset of countries sums over all the corresponding interactions, but they are now split by decades.
} 
Table 7: WTO and LDC Interactions: WTO Formal Membership

\begin{tabular}{|c|c|c|c|}
\hline & $\begin{array}{c}\text { OLS } \\
(1) \\
\end{array}$ & $\begin{array}{c}\mathrm{PPML}^{\dagger} \\
(2) \\
\end{array}$ & $\begin{array}{c}\text { PPML } \\
(3) \\
\end{array}$ \\
\hline NRTP & $\begin{array}{l}-0.038 \\
(0.044)\end{array}$ & $\begin{array}{c}0.242^{* * *} \\
(0.044)\end{array}$ & $\begin{array}{c}0.208^{* * *} \\
(0.043)\end{array}$ \\
\hline $\mathrm{NRTP} \times \mathrm{LDC}$ & $\begin{array}{c}0.210^{* * *} \\
(0.080)\end{array}$ & $\begin{array}{c}-0.186^{* *} \\
(0.086)\end{array}$ & $\begin{array}{l}-0.073 \\
(0.092)\end{array}$ \\
\hline $\mathrm{NRTP} \times \mathrm{WTO}$ & $\begin{array}{c}0.064 \\
(0.044)\end{array}$ & $\begin{array}{c}-0.324^{* * *} \\
(0.052)\end{array}$ & $\begin{array}{c}-0.335^{* * *} \\
(0.052)\end{array}$ \\
\hline $\mathrm{NRTP} \times \mathrm{LDC} \times \mathrm{WTO}$ & $\begin{array}{c}0.105 \\
(0.094)\end{array}$ & $\begin{array}{c}0.787^{* * *} \\
(0.109)\end{array}$ & $\begin{array}{c}0.781^{* * *} \\
(0.118)\end{array}$ \\
\hline WTO & $\begin{array}{c}0.036 \\
(0.037)\end{array}$ & $\begin{array}{c}0.151^{* *} \\
(0.077)\end{array}$ & $\begin{array}{c}0.122 \\
(0.077)\end{array}$ \\
\hline $\mathrm{WTO} \times \mathrm{LDC}$ & $\begin{array}{c}0.126 \\
(0.082)\end{array}$ & $\begin{array}{c}0.461^{* * *} \\
(0.129)\end{array}$ & $\begin{array}{c}0.493^{* * *} \\
(0.138)\end{array}$ \\
\hline PTA & $\begin{array}{c}0.301^{* * *} \\
(0.065)\end{array}$ & $\begin{array}{c}0.675^{* * *} \\
(0.040)\end{array}$ & $\begin{array}{c}0.607^{* * *} \\
(0.042)\end{array}$ \\
\hline $\mathrm{PTA} \times \mathrm{LDC}$ & $\begin{array}{l}-0.210 \\
(0.154)\end{array}$ & $\begin{array}{l}-0.002 \\
(0.110)\end{array}$ & $\begin{array}{c}0.127 \\
(0.177)\end{array}$ \\
\hline $\mathrm{PTA} \times \mathrm{WTO}$ & $\begin{array}{c}0.241^{* * *} \\
(0.064)\end{array}$ & $\begin{array}{c}-0.303^{* * *} \\
(0.040)\end{array}$ & $\begin{array}{c}-0.247^{* * *} \\
(0.041)\end{array}$ \\
\hline $\mathrm{PTA} \times \mathrm{WTO} \times \mathrm{LDC}$ & $\begin{array}{c}0.111 \\
(0.174)\end{array}$ & $\begin{array}{c}0.097 \\
(0.183)\end{array}$ & $\begin{array}{c}0.061 \\
(0.220)\end{array}$ \\
\hline $\begin{array}{l}\text { NRTPs for LDC WTO nonmembers } \\
\text { NRTP + NRTP } \times \text { LDC }\end{array}$ & $\begin{array}{c}0.172^{* *} \\
(0.074)\end{array}$ & $\begin{array}{c}0.056 \\
(0.076)\end{array}$ & $\begin{array}{c}0.135 \\
(0.083)\end{array}$ \\
\hline $\begin{array}{l}\text { NRTPs for non-LDC WTO members } \\
\text { NRTP + NRTP } \times \text { WTO }\end{array}$ & $\begin{array}{c}0.025 \\
(0.030)\end{array}$ & $\begin{array}{c}-0.082^{* * *} \\
(0.023)\end{array}$ & $\begin{array}{c}-0.127^{* * *} \\
(0.022)\end{array}$ \\
\hline $\begin{array}{l}\text { NRTPs for LDC WTO members } \\
(\text { NRTP + NRTP } \times \text { LDC + NRTP } \times \text { WTO } \\
+ \text { NRTP } \times \text { LDC } \times \text { WTO) }\end{array}$ & $\begin{array}{c}0.340^{* * *} \\
(0.057)\end{array}$ & $\begin{array}{c}0.519^{* * *} \\
(0.064)\end{array}$ & $\begin{array}{c}0.580^{* * *} \\
(0.072)\end{array}$ \\
\hline Observations & 852,052 & 852,052 & $1,431,430$ \\
\hline
\end{tabular}




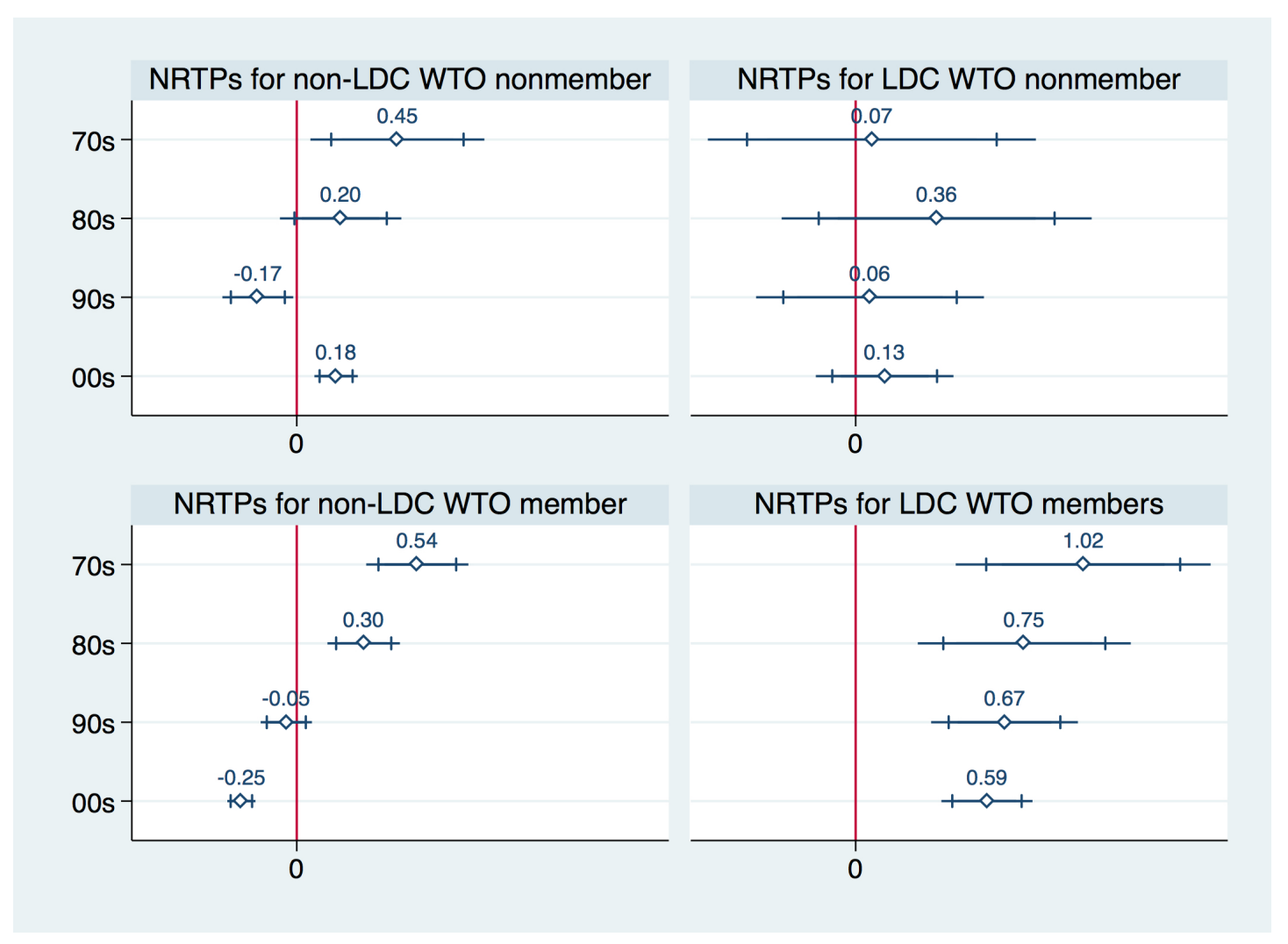

Figure 4: Heterogeneous Eects Over Time

Among LDCs, the trade effect for WTO members is positive and significant for all periods, even though the magnitude of the point estimates declines slightly over time. On the other hand, the effect for LDCs that are not WTO members is small and never statistically different from zero. This shows that our conclusions about the interplay between NRTPs and WTO membership for LDCs are not contingent on any specific period.

For non-LDCs, results are more erratic. The estimates for WTO members indicate a clear decline of the impact of NRTPs over time. Among WTO nonmembers, the NRTP trade effects resonate with those of members in the 1970's and 1980's, but diverge in later years. Specifically, in the 2000's we observe a positive and statistically significant effect for WTO nonmembers, but the inverse for WTO members. This could reflect the fact that MFN tariff levels have decreased considerably in that period, so the value of NRTPs fell for those in the WTO enjoying MFN access to developed markets. Absent WTO membership, however, NRTPs remained a valuable way to access those markets.

Overall, the disaggregation of trade effects by decade confirms that the trade effect of NRTPs is heterogeneous over time. That heterogeneity indicates that the trade impact of NRTPs for non-LDCs tend to be context-specific. On the other hand, our previous results 
for LDCs are valid throughout the whole period of analysis: NRTPs help the exports of LDCs considerably, but only if they are WTO members.

\subsubsection{Disentangling the NRTP Trade Effect for LDCs}

The finding that NRTPs promote the exports of LDCs only if they are members of the WTO is somewhat puzzling, since the NRTP margin of preference tends to be larger if the beneficiary country is not in the WTO. We have argued that this may reflect reforms that are either induced by or a pre-condition for WTO entry, or reflect other institutional and economic characteristics that correlate with WTO membership. Here we offer a first look at what those factors may be.

To avoid a proliferation of interaction terms, we restrict the sample to LDC exporters. We then interact the NRTP and NRTP* WTO variables with a dummy that indicates that the country is in the 'top' third of the ranking of characteristic $X$, where $X$ represents one of following variables: (1) GDP per capita; (2) a democracy index, to proxy for institutional quality; ${ }^{32}$ (3) the share of iron and steel production in GDP, to proxy for comparative advantage in manufacturing goods; and (4) national consumption of primary energy divided by GDP, to proxy for the level of economic activity more broadly. The last two variables are components of what forms the Correlates of War's index of National Material Capabilities (Singer et al., 1972). The bottom of Table 8 describes the data sources for each variable.

Table 8 shows the total effect for each group of LDCs in the PPML estimation. For WTO nonmembers, the trade effect of NRTPs is always statistically indistinguishable from zero. For WTO members, the distinction by GDP per capita makes no difference, but a higher level of each of the other three variables is associated with a larger NRTP effect (a greater importance of iron and steel in the economy is only marginally significant, though).

The results thus indicate that broader national capabilities and stronger institutions may play a central role in explaining why WTO membership increases the effectiveness of nonreciprocal preferences for LDCs. This is, however, just a first look at the characteristics that lie behind the mechanisms through which this happens, and further research is certainly needed to improve our understanding of those channels.

\footnotetext{
${ }^{32}$ Ideally, we would like to use a variable describing the rule of law to proxy for the quality of institutions in a country. However, the time spans of existing indexes are restricted to more recent years.
} 
Table 8: NRTP effects among LDCs by national traits

\begin{tabular}{lcccc}
\hline \hline & $\begin{array}{c}\text { GDP } \\
\text { Per Capita } \\
(1)\end{array}$ & $\begin{array}{c}\text { Democracy } \\
\text { Index } \\
(2)\end{array}$ & $\begin{array}{c}\text { Iron and Steel } \\
\text { Production } \\
(3)\end{array}$ & $\begin{array}{c}\text { Energy } \\
\text { Consumption } \\
(4)\end{array}$ \\
\hline \hline Non-WTO member (low X) & -0.050 & -0.128 & -0.070 & -0.057 \\
& $(0.171)$ & $(0.202)$ & $(0.196)$ & $(0.207)$ \\
Non-WTO member (high X) & -0.084 & 0.354 & 0.155 & -0.230 \\
& $(0.234)$ & $(0.257)$ & $(0.314)$ & $(0.209)$ \\
WTO member (low X) & 0.229 & 0.136 & 0.194 & 0.168 \\
& $(0.150)$ & $(0.184)$ & $(0.178)$ & $(0.179)$ \\
WTO member (high X) & 0.189 & $0.329 *$ & 0.297 & $0.414^{* *}$ \\
& $(0.189)$ & $(0.171)$ & $(0.185)$ & $(0.183)$ \\
\hline Observations & 196,782 & 196,782 & 196,782 & 196,782 \\
\hline \hline
\end{tabular}

Notes: In column 1, X is GDP Per Capita; in column 2, a democracy index; in column 3, production of iron and steel divided by GDP; in column 4, national consumption of primary energy divided by GDP. GDP and GDP per capita are from the World Bank. Production of iron and steel and consumption of primary energy are from the Correlates of War's National Material Capabilities database version 5.0 (Singer et al., 1972). The democracy index is from the Polity IV project (http://www.systemicpeace.org/polityproject.html).

\subsubsection{Additional Robustness Checks}

Different definition for PTAs We aggregate all PTAs (i.e., trade agreements coded 2 to 6 in the Baier-Bergstrand database) into a single dummy. We use that concise definition for PTAs because our focus is on the NRTP trade effect. However, following a large literature that seeks to distinguish the trade effects of different types of PTAs (for example, Baier et al., 2014), we re-run our main specification differentiating across types of PTAs. We find that our key results regarding the NRTP trade effect remain qualitatively unchanged. We do not include the results for brevity, but they are available upon request.

Aggregating data at different time intervals We use data at the year level, as they are collected. As we argued in section 2, we think this is the appropriate approach in our context. But other authors aggregate data at longer time periods - three, four or five years. The main justification is that a single year may not be enough for a full adjustment to a trade agreement. Accordingly, we re-run our main specification aggregating the data at longer time horizons. Again, our main results regarding the NRTP trade effect remain qualitatively unchanged. We do not include the results for brevity, but they are available 
upon request.

\section{Conclusion}

We estimate the aggregate effects of nonreciprocal trade preferences on exports of beneficiary countries. Such preferences have been offered systematically by developed economies to developing ones since the 1970s. Yet to this point we do not know even whether they achieve their most basic purpose of promoting exports of developing countries.

The reason for the existing ambiguity in the literature is three-fold. First, some methodological approaches were not suitable for the analysis. Second, the NRTP data used in some studies were incomplete and sometimes faulty. Third, previous analyses have overlooked heterogeneity in the effects of NRTPs.

Here, we carry out a simple but theoretically consistent gravity analysis of NRTPs using a complete, well-documented dataset. Looking at average effects, little can be concluded about the effectiveness of the preferences. However, once one allows for heterogeneity regarding the level of development of the country and its membership in the World Trade Organization, the picture becomes much clearer.

Nonreciprocal preferences boost exports of the Least Developed Countries, but only if they are members of the WTO. They also promote foreign sales of non-LDCs, but only if they are not members of the WTO. Those results are fairly robust and are not driven by the deeper and wider preferences that LDCs receive in some arrangements (although the effects are stronger in that case). They point to a nuanced relationship between preferential and multilateral liberalization that depends on the country's level of development. In particular, the results suggest that nonreciprocal preferential access can help very poor countries access the markets of rich economies, but participation in the multilateral trading system is a pre-condition for that.

More generally, this paper helps to settle some issues in the literature while hinting at several new avenues for further research. It stresses that the results of nonreciprocal preferences are heterogeneous. On the empirical side, we explore some margins of heterogeneity, but many others are possible, some of which are motivated directly by our analysis. For example, it would be interesting to investigate whether the NRTP effect varies with the type of exit of an agreement (that is, when the country is removed/'graduates' vis-à-vis when it forms a PTA with the donor nation); to evaluate whether the NRTP effect varies with the preference-granting country (the effect may be heterogeneous simply because the 
depth and width of preferences vary, but do more fundamental characteristics of the donor country also matter?); and to explore further the heterogeneity of the effect over time (since many characteristics of the world trading system have changed over the decades).

On the theoretical side, we have argued that the heterogeneous result for non-LDCs probably reflects different margins of preferences that hinge on WTO membership, whereas the heterogeneous result for LDCs seems to reveal institutional characteristics related to (or perhaps induced by) WTO membership. However, here we only speculate about the possible reasons behind our empirical results. Ultimately, they reveal that we need more theoretical work to better guide the empirical analysis so we can more fully understand the implications of nonreciprocal preferences.

\section{References}

Albornoz, Facundo, Irene Brambilla and Emanuel Ornelas. 2018. "The Impact of the Generalized System of Preferences on Firms' Export Performance." Mimeo.

Anderson, James and Eric van Wincoop. 2003. "Gravity with Gravitas: a solution to the border puzzle." American Economic Review 93(1), 170-192.

Bagwell, Kyle and Robert W. Staiger. 1999. "An Economic Theory of GATT." American Economic Review 89, 215-248.

Bagwell, Kyle and Robert W. Staiger. 2002. The Economics of the World Trading System. Cambridge, MA: The MIT Press.

Bagwell, Kyle and Robert Staiger. 2014. "Can the Doha Round be a Development Round? Setting a Place at the Table", in R. C. Feenstra and A. M. Taylor (eds.), Globalization in an Age of Crisis: Multilateral Economic Cooperation in the TwentyFirst Century, Chicago: University of Chicago Press.

Baier, Scott and Jeffrey Bergstrand. 2007. "Do free trade agreements actually increase members' international trade?" Journal of International Economics 71, 72-95.

Baier, Scott, Jeffrey Bergstrand and Michael Feng. 2014. "Economic integration agreements and the margins of international trade." Journal of International Economics 93, 339-350.

Baldwin, Richard and Daria Taglioni. 2006. "Gravity for dummies and dummies for gravity equations." Cambridge: National Bureau of Economic Research Working Paper 12516.

Barbieri, Katherine, Omar Keshk and Brian Pollins. 2009. "TRADING DATA: Evaluating our Assumptions and Coding Rules." Conflict Management and Peace Science 26(5), 471-491. 
Carnegie, Allison. 2013. "Instruments of Coercion: International Institutions and the Sites of Power in International Relations." Mimeo.

Chang, Pao-Li and Myoung-Jae Lee. 2011. "The WTO trade effect." Journal of International Economics 85(1), 53-71.

De Sousa, Jose. 2012. "The currency union effect on trade is decreasing over time." Economics Letters 117(3), 917-920.

Eicher, Theo and Christian Henn. 2011. "In search of WTO trade effects: preferential trade agreements promote trade strongly, but unevenly". Journal of International Economics 83(2), 137-153.

Frazer, Garth and Johannes Van Biesebroeck. 2010. "Trade Growth under the African Growth and Opportunity Act." The Review of Economics and Statistics 92, 128-144.

Garred, Jason and Kyac Lim Kwon. 2017. "Who Gains from Expanded Trade Preferences for the Least Developed Countries?" Mimeo.

Gil-Pareja, Salvador, Rafael Llorca-Vivero and José Antonio Martínez-Serrano. 2014. "Do nonreciprocal preferential trade agreements increase beneficiaries' exports?" Journal of Development Economics 107, 291-304.

Gil-Pareja, Salvador, Rafael Llorca-Vivero and José Antonio Martínez-Serrano. 2017. "The effect of nonreciprocal preferential trade agreements on benefactors' exports." Empirical Economics 52, 143-154.

Gnutzmann, Hinnerk and Arevik Gnutzmann-Mkrtchyan. 2017. "The Trade Effect of GSP Removal: Evidence from Belarus." BEROC Working Paper Series: WP No. 44.

Guimaraes, Paulo and Pedro Portugal. 2010. "A Simple Feasible Alternative Procedure to Estimate Models with High-Dimensional Fixed Effects." Stata Journal 10(4), 628649.

Hakobyan, Shushanik. 2017a. "GSP Expiration and Declining Exports from Developing Countries." Mimeo.

Hakobyan, Shushanik. 2017b. "Export Competitiveness of Developing Countries and US Trade Policy." The World Economy 40(7), 1405-1429.

Head, Keith and Thierry Mayer. 2014. "Gravity equations: workhorse, toolkit and cookbook." In: G. Gopinath, E. Helpman and K. Rogoff (Eds.), Chapter 3, Handbook of International Economics, vol. 4, Elsevier: Amsterdam.

Herz, Bernhard and Marco Wagner. 2011. "The Dark Side of the Generalized System of Preferences." Review of International Economics 19(4), 763-775.

Larch, Mario, Joschka Wanner, Yoto Yotov and Thomas Zylkin. 2017. "The Currency Union Effect: A PPML Re-assessment with High-Dimensional Fixed Effects." Drexel University School of Economics Working Paper Series 2017-7, Drexel University. 
Limao, Nuno. 2016. "Preferential Trade Agreements." In: K. Bagwell and R. W. Staiger (Eds.), Chapter 6, Handbook of Commercial Policy, vol. 1B, Elsevier: Amsterdam.

Liu, Xuepeng. 2009. "GATT/WTO Promotes Trade Strongly: Sample Selection and Model Specification." Review of International Economics 17(3), 429-446.

Liu, Xuepeng. 2016. "Trade Agreements and Economic Growth." Southern Economic Journal 82(4), 1374-1401.

Ornelas, Emanuel. 2016. "Special and Differential Treatment for Developing Countries." In: K. Bagwell and R. W. Staiger (Eds.), Chapter 7, Handbook of Commercial Policy, vol. 1B, Elsevier: Amsterdam.

Rose, Andrew. 2004. "Do We Really Know That the WTO Increases Trade?" American Economic Review 94(1), 98-114.

Santos-Silva, J.M.C. and Silvana Tenreyro. 2006. "The log of gravity." The Review of Economics and Statistics 88 (4), 641-658.

Singer, J. David, Stuart Bremer and John Stuckey. 1972. "Capability Distribution, Uncertainty, and Major Power War, 1820-1965." In: Bruce Russett (ed.), Peace, War and Numbers, Beverly Hills: Sage, 19-48.

Subramanian, Arvind and Shang-Jin Wei. 2007. "The WTO Promotes Trade, Strongly but Unevenly." Journal of International Economics 72(1), 151-175.

Teti, Feodora. 2018. "Trade for Aid or Colonialism 2.0? The Effects of Nonreciprocal Trade Agreements on Firms: Evidence from Peru." Mimeo.

Thelle, Martin, Tine Jeppesen, Christian Gjødesen-Lund and Johannes Van Biesebroeck. 2015. "Assessment of economic benefits generated by the E.U. Trade Regimes towards the developing countries." Mimeo.

Tomz, Michael, Judith Goldstein and Douglas Rivers. 2007a. "Do We Really Know That the WTO Increases Trade? Comment." American Economic Review 97 no. 5, 2005-18.

Tomz, Michael, Judith Goldstein and Douglas Rivers. 2007b. "Institutions in International Relations: Understanding the Effects of the GATT and the WTO on World Trade." International Organization Vol. 61, No. 1, pp. 37-67.

UNCTAD (several years). "Generalized System of Preferences-List of Beneficiaries." UNCTAD.

Zissimos, Ben (ed.). 2018. The WTO and Economic Development. Under review at MIT Press. 


\section{Appendix}

\subsection{List of Better-than-GSP Arrangements}

Table A1: Better-than-GSP Schemes

\begin{tabular}{|c|c|c|}
\hline Donor & Program & Starting Year \\
\hline Australia & South Pacific Regional Trade and Economic Cooperation Agreement & 1981 \\
\hline Australia & Generalized System of Preferences (LDC Subscheme) & 2003 \\
\hline Canada & Commonwealth Caribbean Countries Tariff & 1986 \\
\hline Canada & Generalized System of Preferences (LDC Subscheme) & 2001 \\
\hline Chile & Duty-free treatment for LDCs & 2014 \\
\hline China & Duty-free treatment for LDCs & 2010 \\
\hline E.U. & $\mathrm{GSP}+$ & 2005 \\
\hline E.U. & Trade preferences for countries of the Western Balkans & 2001 \\
\hline E.U. & Everything but Arms & 2001 \\
\hline E.U. & Trade preferences for Pakistan & 2013 \\
\hline Iceland & Generalized System of Preferences (LDC-Specific Scheme) & 2002 \\
\hline India & Duty-Free Tariff Preference Scheme for LDCs & 2008 \\
\hline Japan & Generalized System of Preferences (LDC Subscheme) & 2001 \\
\hline Kazakhstan & Generalized System of Preferences (LDC Subscheme) & 2011 \\
\hline Korea & Preferential Tariff for LDCs & 2008 \\
\hline Kyrgyzstan & Duty-free treatment for LDCs & 2006 \\
\hline Morocco & Duty-free treatment for African LDCs & 2001 \\
\hline New Zealand & South Pacific Regional Trade and Economic Cooperation Agreement & 1981 \\
\hline New Zealand & Generalized System of Preferences (LDC Subscheme) & 2001 \\
\hline Norway $^{\dagger}$ & Generalized System of Preferences & 2002 \\
\hline Switzerland & Generalized System of Preferences (LDC Subscheme) & 1997 \\
\hline Taiwan & Duty-Free Treatment for LDCs & 2004 \\
\hline Thailand & Duty-Free Tariff Preference Scheme for LDCs & 2015 \\
\hline Turkey & Generalized System of Preferences (LDC Subscheme) & 2002 \\
\hline U.S. & Generalized System of Preferences (LDC Subscheme) & 1996 \\
\hline U.S. & African Growth and Opportunity Act & 2001 \\
\hline U.S. & Caribbean Basin Initiative & 2007 \\
\hline
\end{tabular}

Notes: ${ }^{\dagger}$ Norway's GSP-LDC scheme was expanded in 2008 and includes 14 non-LDC low-income countries. 


\subsection{Additional Results}

Table A2: Pre-Trends and Last Years

\begin{tabular}{|c|c|c|c|c|c|c|c|c|c|c|}
\hline & \multicolumn{2}{|c|}{$\mathrm{T}=1$} & \multicolumn{2}{|c|}{$\mathrm{T}=2$} & \multicolumn{2}{|c|}{$\mathrm{T}=3$} & \multicolumn{2}{|c|}{$\mathrm{T}=4$} & \multicolumn{2}{|c|}{$\mathrm{T}=5$} \\
\hline & $\begin{array}{l}\text { OLS } \\
(1) \\
\end{array}$ & $\begin{array}{c}\text { PPML } \\
(2) \\
\end{array}$ & $\begin{array}{l}\text { OLS } \\
(3) \\
\end{array}$ & $\begin{array}{c}\text { PPML } \\
(4) \\
\end{array}$ & $\begin{array}{c}\text { OLS } \\
(5) \\
\end{array}$ & $\begin{array}{c}\text { PPML } \\
(6) \\
\end{array}$ & $\begin{array}{c}\text { OLS } \\
(7) \\
\end{array}$ & $\begin{array}{c}\text { PPML } \\
(8) \\
\end{array}$ & $\begin{array}{l}\text { OLS } \\
(9) \\
\end{array}$ & $\begin{array}{c}\text { PPML } \\
(10)\end{array}$ \\
\hline NRTP & $\begin{array}{c}0.083^{* * *} \\
(0.028)\end{array}$ & $\begin{array}{c}-0.035^{*} \\
(0.019)\end{array}$ & $\begin{array}{c}0.087^{* * *} \\
(0.029)\end{array}$ & $\begin{array}{c}-0.035^{*} \\
(0.020)\end{array}$ & $\begin{array}{c}0.090^{* * *} \\
(0.030)\end{array}$ & $\begin{array}{c}-0.037^{*} \\
(0.020)\end{array}$ & $\begin{array}{c}0.095^{* * *} \\
(0.030)\end{array}$ & $\begin{array}{c}-0.036^{*} \\
(0.021)\end{array}$ & $\begin{array}{c}0.102^{* * *} \\
(0.031)\end{array}$ & $\begin{array}{c}-0.036^{*} \\
(0.021)\end{array}$ \\
\hline NRTP Pre Trend & $\begin{array}{c}0.013 \\
(0.035)\end{array}$ & $\begin{array}{c}0.038 \\
(0.043)\end{array}$ & $\begin{array}{c}0.014 \\
(0.032)\end{array}$ & $\begin{array}{c}0.031 \\
(0.042)\end{array}$ & $\begin{array}{c}0.022 \\
(0.032)\end{array}$ & $\begin{array}{c}0.022 \\
(0.043)\end{array}$ & $\begin{array}{c}0.037 \\
(0.032)\end{array}$ & $\begin{array}{c}0.020 \\
(0.044)\end{array}$ & $\begin{array}{c}0.054^{*} \\
(0.032)\end{array}$ & $\begin{array}{c}0.004 \\
(0.045)\end{array}$ \\
\hline NRTP Last Years & $\begin{array}{l}-0.043 \\
(0.041)\end{array}$ & $\begin{array}{c}0.024 \\
(0.030)\end{array}$ & $\begin{array}{c}-0.090^{* *} \\
(0.038)\end{array}$ & $\begin{array}{c}0.022 \\
(0.029)\end{array}$ & $\begin{array}{c}-0.073^{* *} \\
(0.036)\end{array}$ & $\begin{array}{c}0.022 \\
(0.030)\end{array}$ & $\begin{array}{c}-0.072^{* *} \\
(0.035)\end{array}$ & $\begin{array}{c}0.016 \\
(0.031)\end{array}$ & $\begin{array}{c}-0.085^{* *} \\
(0.034)\end{array}$ & $\begin{array}{c}0.009 \\
(0.031)\end{array}$ \\
\hline WTO & $\begin{array}{c}0.098 * * \\
(0.040)\end{array}$ & $\begin{array}{c}0.165^{* *} \\
(0.079)\end{array}$ & $\begin{array}{c}0.098^{* *} \\
(0.040)\end{array}$ & $\begin{array}{c}0.165^{* *} \\
(0.079)\end{array}$ & $\begin{array}{c}0.098^{* *} \\
(0.040)\end{array}$ & $\begin{array}{c}0.165^{* *} \\
(0.079)\end{array}$ & $\begin{array}{c}0.098^{* *} \\
(0.040)\end{array}$ & $\begin{array}{c}0.165^{* *} \\
(0.079)\end{array}$ & $\begin{array}{c}0.098^{* *} \\
(0.040)\end{array}$ & $\begin{array}{c}0.165^{* *} \\
(0.079)\end{array}$ \\
\hline PTA & $\begin{array}{c}0.496^{* * *} \\
(0.026)\end{array}$ & $\begin{array}{c}0.387^{* * *} \\
(0.020)\end{array}$ & $\begin{array}{c}0.495^{* * *} \\
(0.026)\end{array}$ & $\begin{array}{c}0.387^{* * *} \\
(0.020)\end{array}$ & $\begin{array}{c}0.495^{* * *} \\
(0.026)\end{array}$ & $\begin{array}{c}0.387^{* * *} \\
(0.020)\end{array}$ & $\begin{array}{c}0.495^{* * *} \\
(0.026)\end{array}$ & $\begin{array}{c}0.387^{* * *} * \\
(0.020)\end{array}$ & $\begin{array}{c}0.495^{* * *} \\
(0.026)\end{array}$ & $\begin{array}{c}0.386^{* * *} \\
(0.020)\end{array}$ \\
\hline Observations & 852,052 & $1,431,430$ & 852,052 & $1,431,430$ & 852,052 & $1,431,430$ & 852,052 & $1,431,430$ & 852,052 & $1,431,430$ \\
\hline
\end{tabular}


Table A3: NRTPs, Better-than-GSP, LDCs and WTO membership

\begin{tabular}{|c|c|c|c|}
\hline & $\begin{array}{c}\text { OLS } \\
(1) \\
\end{array}$ & $\begin{array}{c}\text { PPML }^{\dagger} \\
(2) \\
\end{array}$ & $\begin{array}{c}\text { PPML } \\
(3) \\
\end{array}$ \\
\hline NRTP & $\begin{array}{c}0.040 \\
(0.047)\end{array}$ & $\begin{array}{c}0.210^{* * *} \\
(0.042)\end{array}$ & $\begin{array}{c}0.179^{* * *} \\
(0.041)\end{array}$ \\
\hline $\mathrm{NRTP} \times \mathrm{LDC}$ & $\begin{array}{c}0.190^{* *} \\
(0.088)\end{array}$ & $\begin{array}{l}-0.128 \\
(0.161)\end{array}$ & $\begin{array}{c}-0.037 \\
(0.155)\end{array}$ \\
\hline $\mathrm{NRTP} \times \mathrm{WTO}$ & $\begin{array}{l}-0.022 \\
(0.048)\end{array}$ & $\begin{array}{c}-0.290^{* * *} \\
(0.049)\end{array}$ & $\begin{array}{c}-0.302^{\text {*** }}(0.050)\end{array}$ \\
\hline $\mathrm{NRTP} \times \mathrm{LDC} \times \mathrm{WTO}$ & $\begin{array}{l}0.176^{*} \\
(0.104)\end{array}$ & $\begin{array}{c}0.597^{* * *} \\
(0.184)\end{array}$ & $\begin{array}{c}0.692^{* * *} \\
(0.178)\end{array}$ \\
\hline BetterThanGSP & $\begin{array}{c}0.426^{* *} \\
(0.166)\end{array}$ & $\begin{array}{c}0.207 \\
(0.226)\end{array}$ & $\begin{array}{c}0.215 \\
(0.239)\end{array}$ \\
\hline BetterThanGSP $\times$ LDC & $\begin{array}{c}-0.419^{* *} \\
(0.196)\end{array}$ & $\begin{array}{l}-0.215 \\
(0.303)\end{array}$ & $\begin{array}{l}-0.189 \\
(0.313)\end{array}$ \\
\hline BetterThanGSP×WTO & $\begin{array}{c}-0.574^{* * * *} \\
(0.173)\end{array}$ & $\begin{array}{l}-0.324 \\
(0.233)\end{array}$ & $\begin{array}{c}-0.345 \\
(0.247)\end{array}$ \\
\hline BetterThanGSP $\times$ LDC $\times$ WTO & $\begin{array}{c}0.441^{* *} \\
(0.210)\end{array}$ & $\begin{array}{c}0.462 \\
(0.320)\end{array}$ & $\begin{array}{c}0.347 \\
(0.329)\end{array}$ \\
\hline WTO & $\begin{array}{c}0.095^{* *} \\
(0.040)\end{array}$ & $\begin{array}{c}0.266^{* * *} \\
(0.082)\end{array}$ & $\begin{array}{c}0.237^{* * *} \\
(0.082)\end{array}$ \\
\hline $\mathrm{WTO} \times \mathrm{LDC}$ & $\begin{array}{c}0.100 \\
(0.081)\end{array}$ & $\begin{array}{c}0.365^{* * *} \\
(0.125)\end{array}$ & $\begin{array}{c}0.386^{* * *} \\
(0.136)\end{array}$ \\
\hline PTA & $\begin{array}{c}0.429^{* * *} \\
(0.050)\end{array}$ & $\begin{array}{c}0.597^{* * *} \\
(0.034)\end{array}$ & $\begin{array}{c}0.547^{* * *} \\
(0.037)\end{array}$ \\
\hline $\mathrm{PTA} \times \mathrm{LDC}$ & $\begin{array}{c}-0.070 \\
(0.141)\end{array}$ & $\begin{array}{c}0.234^{* *} \\
(0.103)\end{array}$ & $\begin{array}{c}0.345^{* *} \\
(0.157)\end{array}$ \\
\hline $\mathrm{PTA} \times \mathrm{WTO}$ & $\begin{array}{c}0.104^{* *} \\
(0.052)\end{array}$ & $\begin{array}{c}-0.235^{* * *} \\
(0.035)\end{array}$ & $\begin{array}{c}-0.195^{* * *} \\
(0.037)\end{array}$ \\
\hline $\mathrm{PTA} \times \mathrm{WTO} \times \mathrm{LDC}$ & $\begin{array}{c}-0.121 \\
(0.160)\end{array}$ & $\begin{array}{l}-0.148 \\
(0.181)\end{array}$ & $\begin{array}{l}-0.182 \\
(0.210)\end{array}$ \\
\hline Observations & 852,052 & 852,052 & $1,431,430$ \\
\hline
\end{tabular}

Notes: Standard errors in parentheses. ${ }^{*},{ }^{* *}$ and ${ }^{* * *}$ indicate statistical significance at the $10 \%, 5 \%$ and $1 \%$ levels, respectively. All regressions include importer and exporter timevarying country fixed effects and symmetric country-pair fixed effects. Standard errors are symmetrically by clustered by country-pairs. ${ }^{\dagger}$ PPML regression with same sample used in OLS regression. 


\subsection{Changes in Policy Variables}

Here we make a more detailed assessment of the changes in the main explanatory variables. We focus on changes of NRTP status and on overall entries and exits among LDC exporters. As in the main text, we document changes in preferences following variable definitions in section 2. Naturally, an abundance of individual reasons drives countries in their trade policy decisions. Nonetheless, there are general, detectable patterns in the country-pairtime variations. We detail them below.

In Table A4 we discriminate between the reasons why the NRTP variable drops from 1 to 0 . There are two possibilities: either preferences are suspended and beneficiaries lose their preferential tariffs, ${ }^{33}$ or countries form a PTA embracing reciprocal liberalization. ${ }^{34}$ Observe that, except for the 1980's, NRTP exits due to PTA formation have outnumbered the pure NRTP suspensions. This suggests that NRTPs and PTAs are not necessarily mutually exclusive trade policy alternatives. Instead, nonreciprocal liberalization may be the first stage in a sequential process of trade integration between developing and developed economies.

Table A4: Exits from NRTPs

\begin{tabular}{crr}
\hline Decade & PTA formation & NRTP suspension \\
\hline 1950 's & 0 & 0 \\
1960 's & 0 & 0 \\
1970 's & 46 & 4 \\
1980 's & 15 & 137 \\
1990 's & 125 & 100 \\
2000 's & 1,245 & 851 \\
\hline
\end{tabular}

In Table A5 we show how NRTP entries and exits vary between members and nonmembers of the WTO. As about every country extending nonreciprocal preferences is also a WTO member, ${ }^{35}$ Table A5 refers exclusively to the WTO status of the beneficiary country. Notice that the number of new preferential arrangements for nonmembers peaked in the 2000's, even though WTO memberships has grown over time, with just a few countries outside the organization nowadays. Furthermore, exits exceeded entries for WTO members in the 2000's, while the reverse happened among nonmembers. All in all, the table shows that concession of nonreciprocal preferences to countries excluded from the world trading

\footnotetext{
${ }^{33}$ Absent PTA formation, the end of NRTPs is usually given by graduation, but countries may also lose eligibility when failing to fulfill some general pre-conditions established by preference-granting countries, like the existence of political pluralism and the rule of law.

${ }^{34}$ Notice that the sum of columns "PTA formation" and "NRTP suspension" equals the column "NRTP/exit" from Table 1 in the main text.

${ }^{35}$ There are a few exceptions, like Russia offering NRTPs to Afghanistan since 1994, even though it became a WTO member only in 2011.
} 
system represents a growing share of overall NRTPs. This general trend is consistent with movements like the recent reform of the European GSP and new nonreciprocal schemes that are exclusive for least developed nations.

\begin{tabular}{lrrrr}
\multicolumn{2}{l}{ Table A5: Changes in NRTPs by WTO affiliation } \\
\hline Decade & \multicolumn{2}{c}{ WTO mbr. } & \multicolumn{2}{c}{ WTO non-mbr. } \\
& Entry & Exit & Entry & Exit \\
\hline 1950 's & 1 & 0 & 0 & 0 \\
1960 's & 121 & 0 & 8 & 0 \\
1970 's & 1,579 & 30 & 657 & 20 \\
1980 's & 440 & 130 & 139 & 22 \\
1990 's & 176 & 166 & 346 & 59 \\
2000 's & 1,419 & 1,741 & 1057 & 355 \\
\hline
\end{tabular}

In Table A6 we reproduce Table 1 but only when exporters are LDCs. The table portrays LDCs as longtime active members of the international trading system, notwithstanding their political and economic frailties. However, NRTP, WTO and PTA entries are more numerous in the 2000's. ${ }^{36}$ Remarkably, preferences for LDCs in the 2000's were extended mainly through NRTPs, not PTAs. This is very different from what we observe in Table 1, and underscores NRTPs as the main form of trade integration for LDCs.

\begin{tabular}{crrrrrr} 
Table A6: Changes in main variables; LDC exporters \\
\hline Decade & \multicolumn{2}{c}{ NRTP } & \multicolumn{2}{c}{ WTO } & \multicolumn{2}{c}{ PTA } \\
& Entry & Exit & Entry & Exit & Entry & Exit \\
\hline 1970 's & 355 & 0 & 48 & 9 & 66 & 0 \\
1980 's & 126 & 28 & 116 & 0 & 106 & 0 \\
1990 's & 109 & 18 & 657 & 803 & 184 & 75 \\
2000 's & 1,068 & 343 & 1,169 & 0 & 448 & 27 \\
\hline
\end{tabular}

Finally, Table A7 splits NRTP entries and exits among LDCs according to WTO membership. Variations across time follow a similar pattern among members and nonmembers. One exception is NRTP exits in the 2000's, which soared among WTO members but remained virtually absent for nonmembers. This is unfortunate, since our results show that NRTPs are most effective precisely for LDCs who are WTO members - and may hint at political economy forces behind the withdrawal of nonreciprocal preferences.

Table A7: Changes in NRTPs among LDCs by WTO affiliation

\begin{tabular}{rrrrr}
\hline Decade & \multicolumn{2}{c}{ WTO mbr. } & \multicolumn{2}{c}{ WTO non-mbr. } \\
& Entry & Exit & Entry & Exit \\
\hline 1970's & 228 & 0 & 127 & 0 \\
1980's & 84 & 23 & 42 & 5 \\
1990's & 67 & 4 & 42 & 14 \\
2000 's & 600 & 277 & 468 & 66 \\
\hline
\end{tabular}

\footnotetext{
${ }^{36}$ Naturally, there are changes also in the list of LDCs. However, the majority of nations were included in the 1970's and new entries have only decreased with time.
} 


\section{CENTRE FOR ECONOMIC PERFORMANCE \\ Recent Discussion Papers}

1577 Matthew Ridlay

Camille Terrier

1576 John Van Reenen

1575 Margarida Madaleno

Max Nathan

Henry Overman

Sevrin Waights

1574 Esteban M. Aucejo

Patrick Coate

Jane Cooley Fruehwirth,

Sean Kelly

Zachary Mozenter

1573 Stephan Heblich

Stephen J. Redding

Daniel M. Sturm

1572 Johannes Beohm

Ezra Oberfield

1571 Hans R. A. Koster

Edward W. Pinchbeck

1570 Holger Breinlich

Elsa Leromain

Dennis Novy

Thomas Sampson

Ahmed Usman
J. Vernon Henderson

Sebastian Kriticos

Dzhamilya Nigmatulina
Fiscal and Education Spillovers from Charter School Expansion

Increasing Differences Between Firms: Market Power and the Macro-Economy

Incubators, Accelerators and Regional Economic Development

Teacher Effectiveness and Classroom Composition

The Making of the Modern Metropolis: Evidence from London

Misallocation in the Market for Inputs: Enforcement and the Organization of Production

How do Households Value the Future? Evidence from Property Taxes

The Economic Effects of Brexit - Evidence From the Stock Market

Measuring Urban Economic Density 
1567 Ester Faia

Sebastien Laffitte

Gianmarco Ottaviano

1566 Brian Bell

Rui Costa

Stephen Machin

1565 Richard Murphy

Felix Weinhardt

Gill Wyness

1564 Paola Conconi

Giovanni Facchini

Max F. Steinhardt

Maurizio Zanardi

1563 Stephen Gibbons

Stephan Heblich

Ted Pinchbeck

1562 Helen Johnson

Sandra McNally

Heather Rolfe

Jenifer Ruiz-Valenzuela,

Robert Savage

Janet Vousden

Clare Wood

1561 Daniel J. Graham

Stephen Gibbons

1560 Daniel S. Jacks

Dennis Novy
Foreign Expansion, Competition and Bank Risk

Why Does Education Reduce Crime?

Who Teaches the Teachers? A RCT of Peerto-Peer Observation and Feedback in 181 Schools

The Political Economy of Trade and Migration: Evidence from the U.S. Congress

The Spatial Impacts of a Massive Rail Disinvestment Program: The Beeching Axe

Teaching Assistants, Computers and Classroom Management: Evidence from a Randomised Control Trial
Quantifying Wide Economic Impacts of Agglomeration for Transport Appraisal: Existing Evidence and Future Directions

Market Potential and Global Growth over the Long Twentieth Century

The Centre for Economic Performance Publications Unit

Tel: +44 (0)2079557673 Email info@cep.lse.ac.uk

Website: http://cep.lse.ac.uk Twitter: @CEP_LSE 